\title{
Lymphocyte Subsets and Inflammatory Cytokines of Monoclonal Gammopathy of Undetermined Significance and Multiple Myeloma
}

\author{
Alessandro Allegra ${ }^{1,+} \oplus$, Vanessa Innao ${ }^{1}$, Andrea Gaetano Allegra ${ }^{1}$, Marta Pugliese ${ }^{1}$, \\ Eleonora Di Salvo $^{2, *}$, Elvira Ventura-Spagnolo ${ }^{3,+}$, Caterina Musolino ${ }^{1,+}$ and \\ Sebastiano Gangemi ${ }^{4, \dagger}$ \\ 1 Division of Hematology, Department of Human Pathology in Adulthood and Childhood "Gaetano Barresi", \\ University of Messina, 98125 Messina, Italy; aallegra@unime.it (A.A.); vinnao@unime.it (V.I.); \\ andrea.allegra@hotmail.it (A.G.A.); martapugliese@libero.it (M.P.); cmusolino@unime.it (C.M.) \\ 2 National Research Council of Italy (CNR)-Institute of Applied Science and Intelligent System (ISASI), \\ 98164 Messina, Italy \\ 3 Legal Medicine Section, Department for Health Promotion and Mother-Child Care, University of Palermo, \\ 90127 Palermo, Italy; elvira.ventura@unipa.it \\ 4 School and Division of Allergy and Clinical Immunology, Department of Clinical and Experimental Medicine, \\ University Hospital “G. Martino”, Via Consolare Valeria SNC, 98125 Messina, Italy; gangemis@unime.it \\ * Correspondence: e.disalvo@isasi.cnr.it; Tel.: +39-0906015436 \\ + These authors contributed to this work equally.
}

Received: 16 April 2019; Accepted: 8 June 2019; Published: 10 June 2019

\begin{abstract}
Almost all multiple myeloma (MM) cases have been demonstrated to be linked to earlier monoclonal gammopathy of undetermined significance (MGUS). Nevertheless, there are no identified characteristics in the diagnosis of MGUS that have been helpful in differentiating subjects whose cancer may progress to a malignant situation. Regarding malignancy, the role of lymphocyte subsets and cytokines at the beginning of neoplastic diseases is now incontestable. In this review, we have concentrated our attention on the equilibrium between the diverse lymphocyte subsets and the cytokine system and summarized the current state of knowledge, providing an overview of the condition of the entire system in MGUS and MM. In an age where the therapy of neoplastic monoclonal gammopathies largely relies on drugs capable of acting on the immune system (immunomodulants, immunological checkpoint inhibitors, CAR-T), detailed knowledge of the the differences existing in benign and neoplastic forms of gammopathy is the main foundation for the adequate and optimal use of new drugs.
\end{abstract}

Keywords: monoclonal gammopathy of undetermined significance; multiple myeloma; T lymphocytes; cytokine; alarmin; inflammation; immunosurveillance

\section{Introduction}

\subsection{General Considerations for MGUS}

The term monoclonal gammopathy of undetermined significance (MGUS) designates the existence of a serum monoclonal protein in subjects with no sign of multiple myeloma (MM) or other related disorders, and represents the most frequent monoclonal gammopathy [1].

In MGUS, the amount of monoclonal Ig in the blood is $<30 \mathrm{~g} / \mathrm{L}$, and monoclonal Ig accounts for $20 \%-70 \%$ of all Ig; thus, in MGUS, the formation of polyclonal Ig is conserved, though habitually decreased compared to healthy subjects. A relevant distinction between MGUS and MM is the finding 
that circulating monoclonal plasma cells are augmented in active MM. In fact, all subjects with MGUS had $<3 \times 10^{6}$ plasma cells per liter [2].

MGUS has been proposed to arise as an effect of the prolonged stimulation of $B$ cells, possibly by microbial and self-antigens [3-7]. While this is generally believed to be benign, a fraction of MGUS subjects are connected with a significantly augmented risk for transformation into MM [8]. Although most MGUS never progresses towards smoldering myeloma (SMM) and MM, the possibility of progression of MGUS into SMM and MM, which are malignant diseases, is estimated at $1 \%$ per year per patient. Currently, there are no criteria in the diagnosis of MGUS that are helpful for differentiating between subjects whose disease will not evolve from those whose disease will progress to a malignant state [1].

\subsection{MGUS Progression: Genetic and Microenvironment Factors}

Numerous theories have been proposed to explicate MGUS progression; among these, one includes the achievement of genetic modifications, although no exclusive genetic modifications have yet been recognized to discriminate subjects with MGUS from those with MM. Karyotypic analysis in subjects with MGUS has been hindered by a low fraction of bone marrow plasma cells that are generally nonproliferating. Nevertheless, in a study that combined fluorescence in situ hybridization (FISH) with cytomorphology, chromosomes 3, 7, 11, and 18 were studied [9]. These chromosomes have been discovered to be aneuploid by FISH in MM. Three hybridization signs for one of these chromosomes were detected in $19(52.8 \%)$ of 36 subjects. Gains of chromosome 3 were more frequent, followed by chromosomes 11, 7, and 18. Thus, the MGUS condition already shows the chromosomal alterations of a plasma cell malignancy [9]. This result indicates that other factors, including alterations of the microenvironment, are likely to be responsible for disease progression [10-12]. The processes implicated in the multistep pathogenesis of monoclonal gammopathies are probably extremely composite and involve viruses; adhesion molecules; cytokines; oncogenes including $\mathrm{Rb}, \mathrm{p} 53$, ras, and $b c \mathrm{l}-2$; and possibly several, though yet unclear, elements that operate in diverse stages of B-cell maturation. For instance, a transformation cause could be an augmented production of B-cell growth factors.

The B-lymphocyte stimulator (BLyS), which is a tumor necrosis factor (TNF) family member essential for the preservation of normal B-cell expansion, stimulated the survival of malignant $B$ cells. BLyS and its receptor were largely expressed on peripheral and bone marrow B cells in MM subjects compared to those with MGUS and healthy subjects. Additionally, serum BLyS concentrations of MM subjects were higher than those of MGUS subjects and controls [13].

McNee et al. reported a process by which the augmented expression of peptidyl arginine deiminase 2 (PADI2) by bone marrow mesenchymal stem cells (BMMSCs) in subjects with MGUS and MM is clearly modified to a malignant plasma cell phenotype. They recognized PADI2 as one of the most greatly upregulated transcripts in BMMSCs from both MM and MGUS subjects, and that PADI2 provokes the upregulation of interleukin-6 expression. Moreover, they reported a new mechanism by which BMMSC alteration in subjects with MM and MGUS increases pro-malignancy signaling by the citrullination of histone H3R26 [14].

It has also been speculated that the acquisition of CD56 (NCAM) expression in MM is a malignancy-related phenomenon. CD56, a cell adhesion molecule, is highly expressed on MM plasma cells, but is not reported on normal plasma cells [15]. High CD56 expression was described in almost all patients with untreated MM, but in none of the MGUS patients [16-18].

\subsection{MGUS Progression and Immunosurveillance}

Escape from immunosurveillance through immunoediting is a hallmark of cancer, and the institution of antitumor immunity necessitates the collaboration of different cell types, including, among others, T cells [19]. Despite the B-cell nature of the condition, significant data demonstrate the crucial contribution of T-cell regulatory activities in the production of the activated B-cell clone in monoclonal gammopathies. The B-cell clonal progenitor that provokes MGUS and myeloma plasma 
cells displays an Ig class switch and a somatic hypermutation of immunoglobulin heavy-chain-variable (Vh) genes, which are events controlled by $\mathrm{T}$ cells [20]. Moreover, several lines of data indicate that the B cell clonal progenitor in MGUS continues to hypermutate Vh region genes, leading to oligoclonal expansion. MGUS and MM subjects also reveal augmented frequencies of $\mathrm{T}$ cells specific for the idiotype (Id) of the monoclonal paraprotein that is found at high levels in the sera of these subjects [21,22]. This statement proposes the possibility of an idiotype-specific feedback activation of B cells in a long-lasting stimulatory loop. However, in this regard, it must be recognized that conflicting results are present in the literature, especially for patients with multiple myeloma. In fact, the presence of idiotype-specific Th1 cells and cytotoxic T cells (CTLs) has been interpreted as a defense mechanism which may limit MM development. Previous studies have shown that Id-specific CTLs are able to lyse myeloma cells [23]. Indeed, attempts to vaccinate patients with their own idiotypes have been pursued in clinical trials [24,25].

Several studies have also confirmed the hypothesis that cytokines and lymphocyte activity may predispose to cancer. In a previous study, we focused on the action of cytokines in MM [26]. In this review, we focus our attention on the equilibrium between the diverse lymphocyte subsets and the cytokine system by assessing the action of cytokines and their impact on MGUS. Therefore, the aim of our research was to summarize what is known about this topic to date, providing an overview of the articles examining the role of the entire system in the onset and progression of MGUS.

\subsection{Immune Paresis and MGUS}

Identified risk factors for disease evolution, from MGUS to MM, comprise the amount and type of M-protein, and the ratio of free light immunoglobulin chains. However, several researchers have demonstrated that the suppression of polyclonal immunoglobulin (PIg) production is a relevant progression factor. In a recent paper, the authors compared PIg concentrations with uninvolved heavy/light chain pair (HLC) concentrations to evaluate the degree of immune paresis depending on the MGUS risk category (0-3). They analyzed 159 MGUS subjects who were divided into four risk groups (0-low, 1-low-intermediate, 2-high-intermediate, and 3-high risk of transformation). The study data demonstrated that the degree of MGUS augmentation increases the risk of identified immune paresis through a decrease in PIg levels [27].

Other studies have demonstrated that the evolution to symptomatic MM from MGUS is connected to immune paresis. In fact, the reduction of any IgM isotypes in subjects with IgG or IgA gammopathy, or any IgA isotypes in patients with IgG or IgM gammopathy, was associated with a more rapid time to progression to MM [28].

However, immune paresis seems to depend on several factors. For instance, immune paresis and MGUS are disassociated in advanced age. It was demonstrated that immune paresis peaks with advancing age, but decreases among very old subjects [29].

In any case, the relationships between alterations of the concentrations of cytokines detected in patients with MGUS, the condition of immune paresis, and the onset of infections, are much more complex than they may seem. Immune paresis induced by the dysregulation of cytokines is able to induce infections [30], but the infections could have a major effect on cellular and cytokine status. Then, are the changes reported in cytokine amount secondary to the defects in immune surveillance, to the proliferation of the clonal plasma cells, or to the infections? Ascertaining the connection between the grade of immunosuppression and the degree of MGUS risk would surely influence our comprehension of the malignant evolution of MGUS.

\subsection{Cellular Subsets}

A greater part of the studies concerning the bone marrow (BM) microenvironment in MGUS and MM subjects have concentrated their attention on the evaluation of stromal cell interactions, which deliver growth and survival signals to plasma cells [31,32]. Conversely, little consideration has 
been dedicated to the specific action of peripheral lymphocytes and lymphocytes infiltrating the BM microenvironment [33-35] (Figure 1).

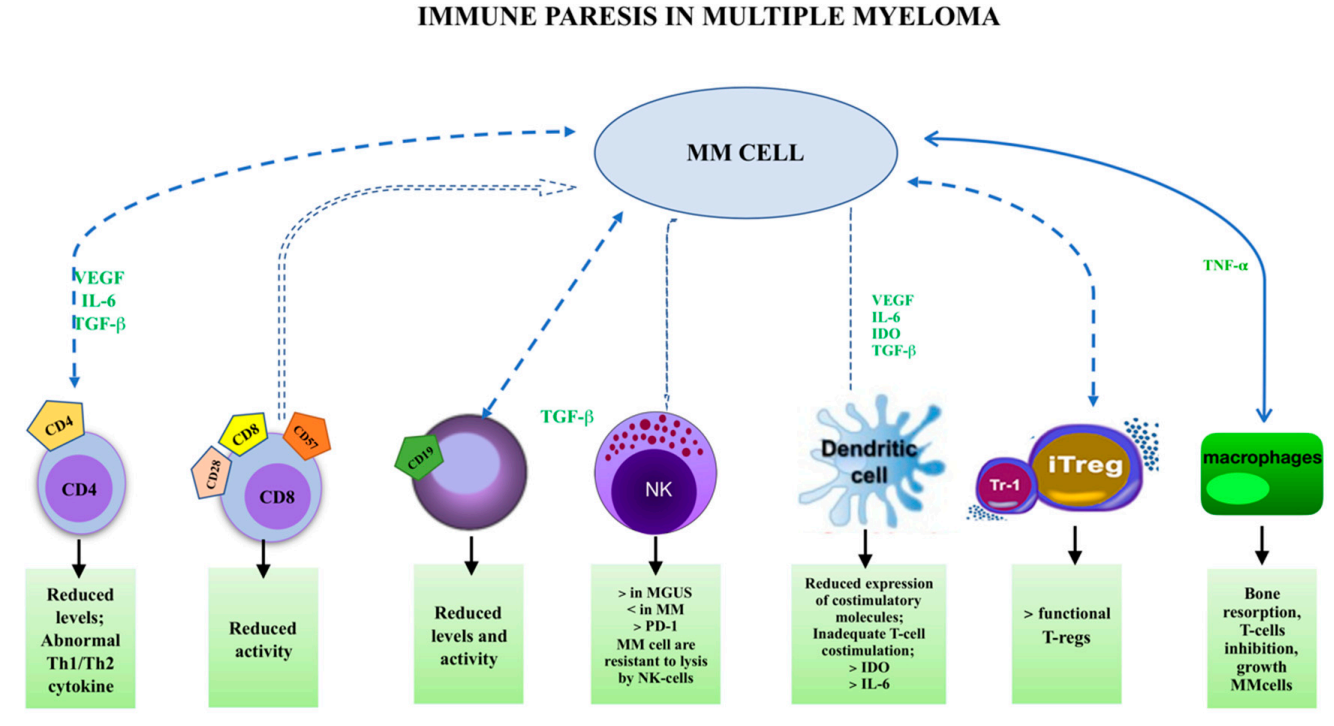

Figure 1. Immune cells involved in multiple myeloma (MM) pathogenesis. The more the arrows are thicker, the most the pathways seems being involved.

Previous reports have demonstrated a reduced number of $\mathrm{CD}^{+} \mathrm{T}$ cells in the peripheral blood (PB) of MM subjects, which has been connected to a reduced $\mathrm{CD} 4^{+} / \mathrm{CD} 8^{+} \mathrm{T}$-cell ratio [36]. Moreover, oligoclonal, chronic growth of circulating $\mathrm{T}$ cells, which may involve up to $25 \%$ of all $\mathrm{T}$ cells, has been reported in the greater part of MM and MGUS subjects [37-39]. In some reports, the increase was limited to $\mathrm{CD} 8^{+} \mathrm{T}$ cells exhibiting an activated cytotoxic phenotype $\left(\mathrm{CD} 8^{+} \mathrm{CD} 57^{+} \mathrm{CD} 28^{-}\right.$perforin $\left.{ }^{+}\right)$ whereas, in other studies, they were also associated with the proliferation of $\mathrm{CD} 4^{+} \mathrm{T}$ cells that exhibited an effector phenotype $\left(\mathrm{CD} 28^{-} \mathrm{CD} 4^{+}\right)$. The specific T-cell increases in subjects with $\mathrm{MM}$ have been connected to a favorable prognosis. It is possible that such augmented T-cell populations could be an effort by the immune system to regulate plasma cell (PC) overgrowth [40-42].

Perez-Andres et al. demonstrated an augmented rate of BM infiltration by $\mathrm{T}$ cells in all subjects with MGUS, MM, and plasma cell leukemia. On the contrary, there was a reduction of $\mathrm{CD} 4^{+} \mathrm{CD} 8^{-}$and $\mathrm{CD} 4^{-} \mathrm{CD} 8^{-} \mathrm{T}$ lymphocytes. Similarly, $\mathrm{CD} 4^{+} \mathrm{CD} 28^{-}$and $\mathrm{CD} 8^{+} \mathrm{CD} 28^{-}$cytotoxic/effector T-cell subsets were also reduced, with an increased expression of TCR-Vb in both $\mathrm{CD}^{+}$and $\mathrm{CD} 8^{+} \mathrm{BM}$ T cells in most of the patient groups [43].

In MGUS subjects, specific T-cell populations seem to be augmented. The CD30 ${ }^{+} \mathrm{T}$-cell subset and concentrations of CD30 expression are increased in activated lymphocytes from healthy subjects over 60 years of age and in MGUS patients, when compared to younger controls ( $<60$ years). Peripheral blood lymphocytes (PBLs) from MGUS subjects and age-matched healthy controls revealed similar concentrations of IL-6 when stimulated with anti-CD3 plus IL-2, and co-stimulation with a soluble form of the CD30 ligand (sCD30L/CD8a) increased anti-CD3-inducible IL-6 production equally in both groups. Nevertheless, MGUS PBLs also delivered IL-6 when stimulated with sCD30L/CD8a alone. This ability was associated with the presence of $\mathrm{CD} 30^{+} \mathrm{T}$ cells in the peripheral blood of MGUS subjects. Moreover, a greater number of MGUS T cells present the CD30 antigen after activation by incubation with idiotype-expressing autologous serum with respect to those triggered by anti-CD3 plus IL-2. These data indicate that numerical modifications in $\mathrm{CD} 30^{+} \mathrm{T}$ cells are typical of MGUS and aging, and that these cells may influence the chronic stimulation of B cells [44].

Beyond the variable rates of cells present in different situations, diverse activity of the different cell subsets could also be relevant for the progression of MGUS into MM. 
The central question is why $\mathrm{CD}^{+} \mathrm{T}$ cells fail to regulate the clonal proliferation of transformed plasma cells in MM [45-47]. An answer to this problem could be the functional characteristics of CD8 ${ }^{+}$ T cells from MGUS and MM subjects, featuring contradictory data. Some studies reported that MM $\mathrm{CD} 8^{+} \mathrm{T}$ cells require protracted in vitro stimulation to produce an effector action, whereas MGUS CD8 ${ }^{+}$ $\mathrm{T}$ cells show relevant ex vivo activity for autologous plasma cells and MM-associated antigens [48]; these results suggest that MM CD8 ${ }^{+} \mathrm{T}$ cells are functionally compromised [49]. Conversely, other research has reported that $\mathrm{MMCD} 8^{+} \mathrm{T}$ cells had adequate reactivity against a human leukocyte antigen (HLA)-A2-restricted tumor-associated antigen peptide [50]. An alternative reason why MM CD8 ${ }^{+}$ $\mathrm{T}$ cells fail to stop tumor progression from MGUS to MM could be that neoplastic plasma cells are altered in the normal presentation of tumor antigens essential for T-cell identification.

These remarks have renewed interest in the immunosurveillance processes of MM growth [51].

Racanelli et al. conjectured that the transformation of MGUS into MM is due to modified plasma cells evading detection by $\mathrm{T}$ cells because of altered antigen processing and presenting machinery (APM) [48]. In fact, immunofluorescence and flow cytometry demonstrated significantly diverse patterns of APM component expression in plasma cells from controls, MGUS, and MM patients. A real-time polymerase chain reaction (RT-PCR) demonstrated that APM changes occurred at the transcriptional level. Cytotoxicity assays revealed that in comparison with MM CD8 ${ }^{+} \mathrm{T}$ cells, MGUS $\mathrm{CD}^{+} \mathrm{T}$ cells caused lysis of a greater number of autologous transformed plasma cells. MGUS transformation directly correlated with calreticulin, tapasin, and calnexin expression levels, and indirectly correlated with LMP2 and LMP10 expression levels; MM status did not correlate with APM levels. APM modifications may allow transformed plasma cells to escape immunosurveillance in the MGUS-MM transformation [52]. It was also demonstrated that the antitumor CD8 T-cell action in the BM of MM subjects was less effective than that of MGUS patients [33,34].

However, several reports have attempted to verify if specific subpopulations capable of generating diverse cytokines could distinguish subjects with MGUS from those with MM.

According to the cytokines produced, $\mathrm{CD} 4^{+} \mathrm{T}$ cells can be classified into numerous subsets, including T helper 1 (Th1), Th2, Th17, and $\mathrm{CD} 4^{+} \mathrm{CD} 25^{+} \mathrm{T}$ regulatory $\left(\mathrm{T}_{\text {reg }}\right)$ cells.

Th1 cells deliver interferon gamma (IFN- $\gamma$ ) and increase the cell-mediated immune response, while Th2 cells produce IL-4 and reduce the Th1 cell-mediated response. Th1/Th2 polarization is determined by numerous genetic and environmental elements and, particularly, by the local levels of cytokines, such as IL-4 and IL-12, that cause the differentiation of naive T lymphocytes to the Th2 and Th1 phenotype [53]. An association between the type 1 immune response and anticancer activity has been proposed [54-56].

The presence of T-cell subsets was analyzed in MGUS subjects and in MM patients with clinical stage I or stage II/III disease. A total of 8 of 9 MGUS subjects, 7 of 12 MM stage I patients, and 3 of 9 patients with MM stage II/III had T cells producing IFN- $\gamma$ and/or IL-2 (T helper (Th1) type-1 cells), while cells producing both Th1 and Th2 or Th0 types of cytokines were more common in subjects with MM, especially in those with MM stage II/III. The number of Th1-type cells was significantly greater in MGUS subjects compared to those of MM stage II/III [22].

Th17 cells produce IL-17A, IL-6, and TNF- $\alpha$ that are involved in increasing the inflammatory response. $\mathrm{T}_{\text {reg }}$ cells reduce effector T-cell growth by generating TGF- $\beta$ and IL-10, which exert immunomodulatory activities. An imbalance between $\mathrm{T}_{\text {reg }}$ and Th17 cells has a central role in inflammatory diseases.

Recently, Th17 cells have been implicated in the onset of MM and its complications. The CD4 ${ }^{+}$ Th1 and $\mathrm{CD}^{+}$Th17 subsets in patients with MM were significantly higher than those in controls, as were the concentrations of T-bet and RORgamma mRNA [57].

$\mathrm{T}_{\text {reg }}$ cells have a crucial action in the protection of self-tolerance and the response against tumor cells. An altered $\mathrm{T}_{\text {reg }}$ action in MM patients could, on the other hand, contribute to MM-related immune dysfunction [58]. 
The activity of $\mathrm{T}_{\text {reg }}$ cells in MM patients has been investigated in numerous studies. However, several in vitro or in vivo results remain unclear. For instance, one study evaluated the number of $T_{\text {reg }}$ cells in the PB of control subjects versus MGUS and MM patients, and revealed a relevant reduction in the number of $\mathrm{T}_{\text {reg }}$ cells. Moreover, these cells were incapable of reducing the growth of $\mathrm{T}$ lymphocytes. However, a different study assessed the function and number of $\mathrm{T}_{\text {reg }}$ cells in the PB and BM of controls and MM patients, and did not demonstrate an alteration in the rate of $\mathrm{T}_{\text {reg }}$ cells [59-61].

Numerous processes could counteract dysregulated $\mathrm{T}_{\text {reg }}$ activity. Indoleamine 2,3-dioxygenase 1 (IDO1) is a tryptophan-catabolizing enzyme. IDO1 oxidizes tryptophan into $\mathrm{N}$-formylkynurenine, which is quickly changed to kynurenine (KYN) by the activity of KYN formamidase [62]. KYN reduces effector $\mathrm{T}$ cells and increases regulatory $\mathrm{T}_{\text {reg }}$ differentiation. Bonanno et al. examined IDO1 expression in subjects with symptomatic MM and in subjects with MGUS or SMM. KYN was augmented in $75 \%$ of subjects with symptomatic $\mathrm{MM}$ and correlated with the increase of $\mathrm{CD} 44^{+} \mathrm{CD} 25^{+} \mathrm{FoxP} 3^{+} \mathrm{T}_{\text {reg }}$ cells and the reduction of NY-ESO-1-specific $\mathrm{CD} 8^{+} \mathrm{T}$ cells. Both the $\mathrm{T}_{\text {reg }}$ increase and reduction of Th1 differentiation were reverted by $\mathrm{D}, \mathrm{L}-1-\mathrm{l}$-methyl-tryptophan, an inhibitor of IDO. These results suggest that IDO1 expression may participate in immune suppression in MM patients [63].

Finally, $\mathrm{V} \gamma 9 \mathrm{~V} \delta 2 \mathrm{~T}$ cells are non-conventional $\mathrm{T}$ cells halfway between adaptive and innate immunity with the capability to react to tumor cells, comprising malignant MM cells. These cells are capable of recognizing and eliminating MM cells in vitro, but they are blocked in the MM microenvironment by immune suppressive circuits. In fact, bone marrow MM V $\gamma 9 \mathrm{~V} \delta 2 \mathrm{~T}$ cells are positive for PD- 1 and do not respond to phosphoantigen stimulation; remarkably, the PD-1 blockade formed by a single drug is inadequate to completely retrieve their antitumor action in vitro, signifying that other factors are implicated in the anergy of $\mathrm{V} \gamma 9 \mathrm{~V} \delta 2 \mathrm{~T}$ cells. These cells may also play a relevant role in the control of MGUS [64].

An increase in $\mathrm{CD} 4{ }^{+} \mathrm{CD} 25^{\text {high }} \mathrm{T}_{\text {reg }}$ cells within the blood and the neoplastic microenvironment is a characteristic of tumors. Moreover, increases in $\mathrm{T}_{\text {reg }}$ cells have been linked to prognosis, tumor stage, and survival. An increased pool of $\mathrm{CD} 4^{+} \mathrm{CD} 25^{\text {high }} \mathrm{T}_{\text {reg }}$ cells in MGUS subjects and MM patients has also been described. In healthy subjects, low-level expression of CD127 on T cells, in addition to the expression of FOXP3, has been associated with $\mathrm{T}_{\text {reg }}$ cell increase [65]. Beyer et al. demonstrated that the increased $\mathrm{FOXP3}^{+}$T-cell populations in subjects with MGUS and MM are exclusively CD127 ${ }^{\text {low }}$ $\mathrm{T}_{\text {reg }}$ cells, and that they are intensely suppressive. A significant percentage of $\mathrm{CD} 127^{\text {low }} \mathrm{FOXP}^{+} \mathrm{T}_{\text {reg }}$ cells presented only low concentrations of CD25, indicating that the previously described increase of $C D 25^{+} \mathrm{T}_{\text {reg }}$ cells was an underestimate of the actual increase [66]. Since MGUS subjects already have augmented frequencies of $T_{\text {reg }}$ cells, it is very probable that the increase of $T_{\text {reg }}$ cells is an early

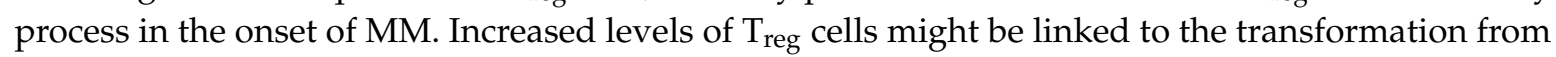
the premalignant condition, that is still under control of the immune system, to the proliferation of malignant plasma cells.

In conclusion, the specific effector activities of tumor-infiltrating $\mathrm{T}$ cells drive the disease towards regression or progression, according to the diverse T-cell subsets $[67,68]$. Actually, Th1 cells exhibit antitumor activity, while Th2 and $\mathrm{T}_{\text {reg }}$ cells are essentially pro-tumor cells $[69,70]$. What is more questionable is the action of Th17 cells that is determined by the cancer model and tumor microenvironment (Figure 1).

\subsection{MGUS and Bone Marrow Cell Populations}

In order to provide a more comprehensive scenario, we report the changes seen in other cell populations in patients with MGUS and MM.

Key cellular elements of both the normal and transformed bone marrow niche are BMMSCs. There is considerable evidence to suggest that BMMSCs from MGUS and MM patients are phenotypically diverse compared to those derived from control subjects [71-76]. Moreover, the BM microenvironment is altered by the malignant plasma cells. An augmented number of macrophages/monocytes has been demonstrated in the BM of MM subjects compared to healthy controls. Tumor-associated macrophages 
(TAMs) are generally divided into two diverse subtypes: M1 TAMs (tumoricidal) and M2 TAMs (immunosuppressive). M2 TAMs are involved in the generation of a medullary environment with immunosuppressive activity by angiogenesis through vascular endothelial growth factor (VEGF) generation. These M2 TAMs have been demonstrated to augment in MM bone marrow and this increase is linked to poorer survival [77,78].

Plasmacytoid dendritic cells are augmented in the BM of MM subjects and promote Th22 cell differentiation. Di Lullo et al. reported that the number of IL- $22^{+} \mathrm{IL}-17^{-} \mathrm{IL}-13^{+} \mathrm{T}$ cells is considerably augmented in peripheral blood and BM of stage III and relapsed/refractory MM subjects with respect to control subjects and subjects with asymptomatic or stage I/II disease. Th22 cells cloned from the BM of MM subjects were CCR $6{ }^{+} \mathrm{CXCR} 4^{+} \mathrm{CCR} 4^{+} \mathrm{CCR} 10^{-}$and delivered IL-22 and IL-13, but not IL-17. A portion of MM cell lines and primary tumors aberrantly exhibited IL-22RA1 and IL-22-induced STAT-3 phosphorylation, cell proliferation, and resistance to drug-induced cell death in MM cells. IL-13 treatment of normal BM mesenchymal stromal cells caused adhesion molecule upregulation, STAT-6 phosphorylation, and augmented IL-6 delivery, and drastically promoted MM cell proliferation compared with untreated BM mesenchymal stromal cells [67].

\subsection{Inflammation, Cytokines, and MGUS}

That an imbalance of T-lymphocyte subsets may play a relevant role in MM $[79,80]$ and an imbalanced pattern of cytokine production by circulating PB T cells was demonstrated in both MGUS and MM subjects [81].

Several chemokines and cytokines have been implicated in the crosstalk between the bone marrow stroma and plasma cells. Interleukin (IL) production by the cells of the BM microenvironment has been demonstrated to play a role in the malignant plasma cell phenotype; firstly, by augmenting the resistance to cell death stimuli, and secondly, by downregulating differentiation markers [82-86].

Chronic cancer-associated inflammation is demonstrated in hematological malignancies, especially in $\mathrm{MM}$, and a diverse cellular and humoral pattern associated with this phenomenon could have an essential role in the onset and progression of monoclonal gammopathies.

In fact, it is known that cytokines are involved in both inflammatory and anti-inflammatory mechanisms, and are part of a system that comprises genes and polymorphisms. Several of these elements that are modified in the serum, or in the BM, of MM patients have proinflammatory actions, such as IL-1, IL-6, IL-12, IL-15, IL-16, IL-17, IL-18, IL-22, IL-23, TNF- $\alpha$, and IFN- $\gamma$, while others have anti-inflammatory actions, such as IL-1R $\alpha$, IL-4, IL-10, IL-11, TGF- $\beta 1$, heat shock proteins (HSPs), and lipoxin A4.

MM is classically exemplified by an altered cytokine system with augmented concentrations of inflammatory cytokines.

In MGUS and MM, chronic inflammation is able to modify the configuration and the function of the monoclonal (mc) Ig generated by the clonal plasma cells by the sialylation of Ig fragment crystallizable (Fc) region. Bosseboeuf et al. studied the sialylation of purified $\mathrm{mc}$ and polyclonal (pc) IgGs from MGUS and MM subjects, in comparison to pc IgGs from healthy controls [87]. The inflammatory condition of subjects was evaluated via the dosage of 40 inflammation-linked cytokines. While pc IgGs from MGUS and MM subjects demonstrated heterogeneity in sialylation, mc IgGs from both MGUS and MMM subjects revealed very low sialylation. Furthermore, mc IgGs from MM subjects were less sialylated than mc IgGs from MGUS subjects. Concerning inflammation, 14 cytokines were equally increased in MGUS and MM compared to healthy subjects. MM diverged from MGUS by greater concentrations of IL-11, RANTES, hepatocyte growth factor (HGF), and stroma cell-derived factor 1 alpha (SDF-1- $\alpha$ ). MGUS and MM subjects exhibiting hyposialylated pc IgGs had considerably greater concentrations of IL- 6 , IL-17, IL-33, TGF- $\beta 1$, HGF, and tumor necrosis factor- $\alpha$ compared to subjects with hypersialylated pc IgGs.

Moreover, MM endothelial cells (ECs) express more HGF and activated cMET versus MGUS ECs and control ECs. The HGF/cMET pathway controls numerous functions of EC in MM subjects, 
comprising motility, adhesion and, ultimately, the angiogenetic process as a whole. Suppression of this pathway can modify these actions when the inhibition occurs simultaneously with the administration of drugs such as bortezomib or lenalidomide, both in vitro and in vivo. It therefore appears evident that an autocrine HGF/cMET loop supports MM angiogenesis and that this could be a novel target to control angiogenesis in MM patients [88].

Analogously, SDF-1 (CXCL12), a chemokine that controls several systems associated with MM malignant evolution, acts through the specialized receptor CXCR4, which is present on the membrane of MM cells. SDF-1- $\alpha$ regulates the homing of plasma cells in MM patients [89].

In a previous manuscript, we analyzed the inflammatory and anti-inflammatory systems by evaluating the actions of cytokines and their impact on MM [26]. In this section of our review, we have summarized the evidence available regarding this equilibrium investigation of the action of inflammatory and anti-inflammatory cytokines in the onset and progression of MGUS.

\subsection{Inflammatory Cytokines and MGUS}

IL-1 promotes the growth of myeloma cell lines and indirectly operates on myeloma plasma cells through IL-6 generation via a prostaglandin $\mathrm{E}_{2}\left(\mathrm{PGE}_{2}\right)$ loop [90]. Normal plasma cells do not deliver IL-1b; nevertheless, abnormal IL-1b generation by myeloma cells has been demonstrated at both the mRNA and protein levels in numerous reports. Employing myeloma cells, Lichtenstein and colleagues [91] identified IL-1b at the protein level, and Klein et al. [92] highlighted strong IL-1b gene expression by in situ hybridization. Cozzolino et al. demonstrated that culture supernatants of plasma cells from all 12 subjects with MM contained high concentrations of IL-1b [93]. On the contrary, plasma cells from MGUS subjects had undetectable concentrations of IL-1b. By employing flow cytometric sorting to enrich plasma cells and RT-PCR for cytokine expression, Donovan et al. confirmed that IL-1b mRNA is produced by plasma cells from all MM subjects but is not measurable in the plasma cells of most MGUS subjects [94] (Figure 2a,b).

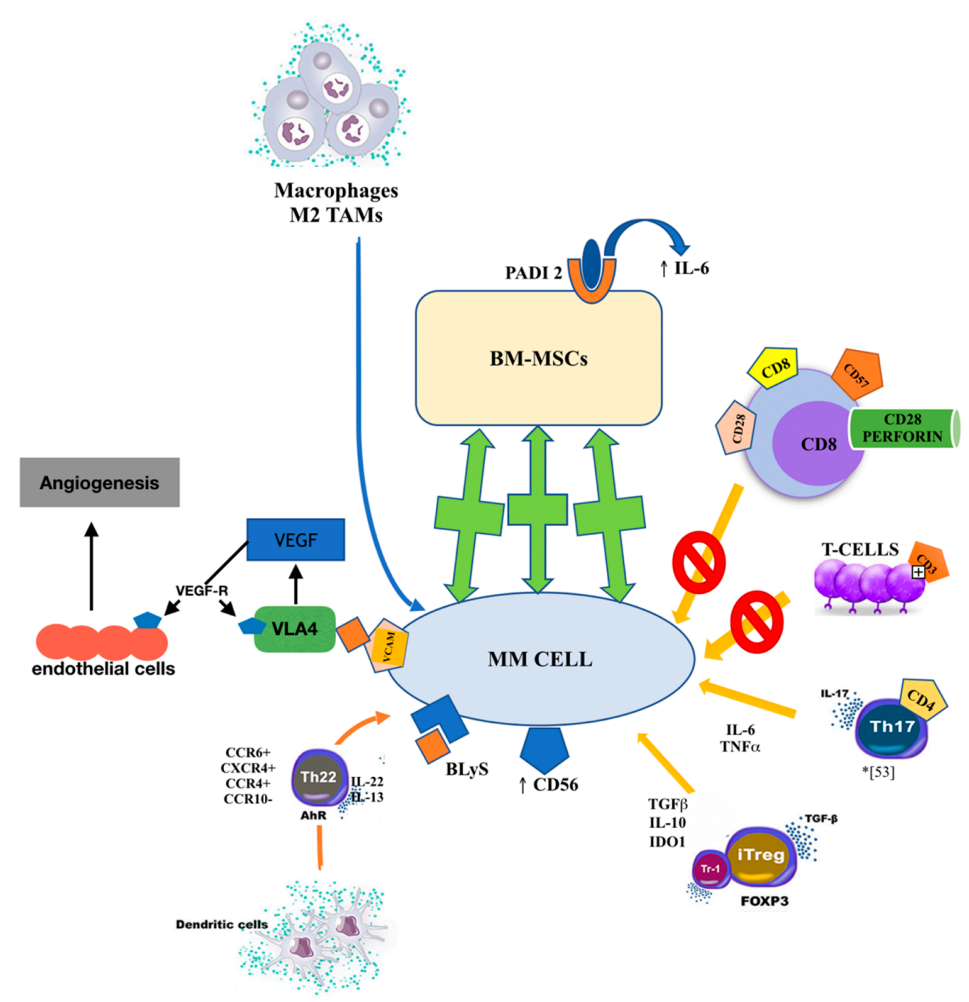

Figure 2. Cont. 


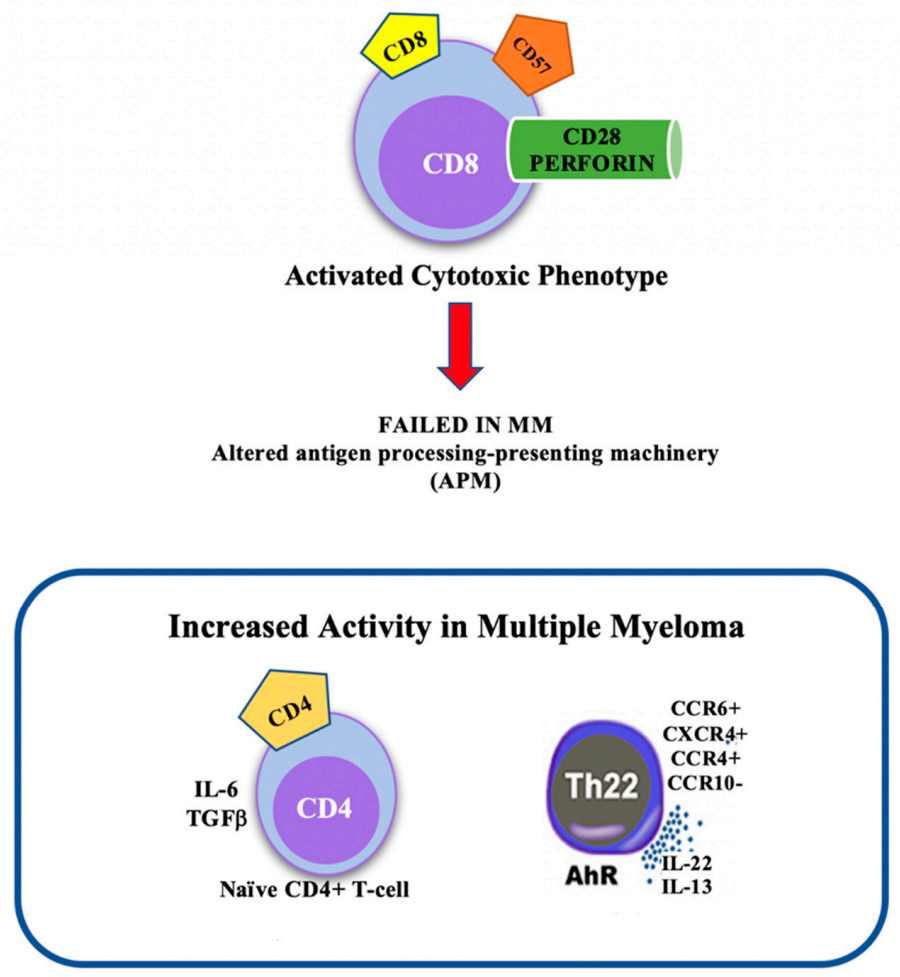

Figure 2. Cytokines and cell subsets involved in the multiple myeloma (MM) peripheral microenvironment. (a). Cytokines and cell subsets involved in MM bone marrow microenvironment. (b). Cytokines and cell subsets involved in MM peripheral microenvironment.

Under such analysis, a question arises: Could anomalous IL-1b production be participating in the transformation from MGUS to myeloma?

Hawley et al. employed an animal model of myeloma that demonstrates the relevance of IL-1 expression in provoking a disease that mimics human MM [95,96]. Employing a method that uses retroviral-mediated gene transfer, the authors inserted IL-1 cDNA into an IL-6-dependent B-cell system. After the administration of these IL-1-producing B cells into syngeneic mice, these cells were shown to "home" to the BM and cause lytic bone lesions [96]. Another report has demonstrated that the anomalous expression of IL-1 can modify adhesion molecules, such as ICAM and CD44, on the surface of mouse plasmacytoma cells [97]. An analogous process may happen in human myeloma, in which anomalous expression of IL-1b provokes augmented expression of adhesion molecules, such as CD54, CD56, CD44, and VLA-4, on monoclonal plasma cells [98-101].

The etiology of acquired IL-1b expression in MM is unclear. However, the IL-1b gene is extremely inducible, and its expression can be modified by several cellular and microbial elements [102]. The action of Kaposi's sarcoma-associated herpesvirus (KSHV) in the onset of MM has been described [103]. Moreover, Epstein-Barr virus, human immunodeficiency virus-1, and respiratory syncytial virus have been demonstrated to upregulate IL-1 expression either directly by acting with genomic sequences or indirectly by modifying concentrations of transcription factors implicated in IL-1b expression [104-106].

Serum and urinary concentrations of the soluble IL-2R (sIL-2R) were considerably augmented in MM subjects compared to healthy subjects, and this increase was directly correlated with disease activity. MM subjects with active disease had considerably greater concentrations than those with stable disease. Compared to healthy subjects, enriched B-cell (but not T-cell) cultures from peripheral blood mononuclear cells (PBMCs) demonstrated significantly augmented amounts of IL-2R+ cells in MM and MGUS. However, the highest amounts were described in active MM compared with stable MM 
and MGUS. Moreover, $16 \%$ of all MM subjects, as opposed to $9 \%$ of MGUS subjects, had well-defined BM IL-2R+ plasma cell populations. The results suggest that an alteration of the IL-2/IL-2R system is more evident in active MM than in MGUS [107].

Concerning IL-3 activity in MM subjects, this cytokine promotes the growth of myeloma plasma cells in vitro, but it is essentially implicated in the differentiation of peripheral blood nonadherent mononuclear cells into mature plasma cells [108].

MM subjects have greater serum IL-3 concentrations than those with MGUS. Moreover, IL-3 differentiates PBMCs from MM, but not MGUS, subjects into mature plasma cells [108].

In monoclonal gammopathies, IL-6 has been recognized as a crucial growth factor for human myeloma cells [37]. IL-6 serum concentrations have been correlated with tumor mass and prognosis in MM patients.

A greater proportion of myeloma cells do not generate IL-6 in vivo, but a minority that do produce autocrine IL-6 have been reported [109]. The principal source of IL-6 is paracrine production by BM stromal cells [110-112]. An augmented proportion of T cells producing IL-6 were described in MM subjects with active disease (at diagnosis and relapsing) with respect to subjects in remission or with MGUS. Evaluation of serum IL- 6 concentrations revealed that the altered IL- 6 production by T cells and defective antitumor Th1 cell action were correlated with increased concentrations of IL-6. In vitro experiments of PHA- and anti-CD3/anti-CD28 monoclonal antibodies (MoAbs) stimulation of PBMCs demonstrated the capability of lymphocytes from MM subjects to differentiate into the Th1 subset in the presence of rIL-12. On the contrary, adding exogenous rIL- 6 altered IFN- $\gamma$ production by rIL-12-prompted T cells. The inhibition of Th1 polarization of the immune response by IL- 6 occurred directly on T cells and was not mediated by dendritic cells. Assessment of the ability of MM-derived dendritic cells (DCs) to promote the cell growth of allogenic T lymphocytes and produce IL-12 in vitro, in fact, indicated that MM-derived DCs were functionally active. Taken together, these results suggest that augmented IL-6 production by peripheral $\mathrm{T}$ lymphocytes influences the immune dysfunction described in MM and allows myeloma cells to escape immune surveillance by inhibiting the antitumor Th1 immune response [113].

A correlation between serum concentrations of IL- 6 and the different status of monoclonal gammopathies has been reported by several works. Thus, serum concentrations of IL-6 are augmented in subjects with symptomatic MM compared to subjects with asymptomatic disease and MGUS. Moreover, the highest concentrations were demonstrated in subjects with an advanced disease refractory to treatment [114]. The percentage of MGUS subjects with an increased serum IL-6 concentration ranged from $15 \%$ to $35 \%$ [115].

Bataille et al. stated that only one out of their 22 subjects with MGUS had an increased serum IL-6 concentration, and this was the only subject where evolution into MM occurred after two years of follow-up [116].

Papadaki et al. described augmented serum levels of IL-6 and soluble IL-6 receptor (sIL-6R) in 48\% of subjects with MM, while normal sIL-6R levels were described in a greater number of subjects with MGUS [117]. However, Soutar et al. described augmented serum concentrations of IL-6 in subjects presenting with both MGUS and MM [118].

These discrepancies may be due to the diverse techniques that have been employed to assess IL-6 activity. Moreover, IL-6 concentrations exhibit daily diurnal (morning and afternoon) modifications [119]. IL-6 has a short half-life, thus, serum concentrations inadequately correlate with local production and only reproduce the part not bound to cellular receptors. For this reason, a single evaluation of serum IL-6 should be treated with caution.

In an effort to longitudinally study the action of serum IL-6 levels in MGUS subjects and to establish the predictor significance of this cytokine in the transformation from MGUS to MM, Blade et al. compared the IL-6 concentrations of MGUS patients to those of controls. After a median follow-up of seven years from the initial cytokine assessment, nine MGUS subjects had progressed to MM. However, 
the actuarial probability of evolution in MGUS subjects with augmented IL-6 concentrations was not significantly higher than in those with normal levels [120].

Furthermore, several studies have considered the clinical significance of soluble IL-6 receptor levels (sIL-6R) in subjects with plasma cell dyscrasias, with similar results. The sIL-6R concentrations in malignant gammopathies are higher than in MGUS [117,121].

However, in another report, among healthy subjects and MGUS and MM patients, sIL-6R levels were augmented analogously in MGUS and MM [122].

Finally, IL-6 activity in normal plasma cells (nPCs) and abnormal plasma cells (aPCs) is CD126(subunit of IL-6 receptor) dependent. Salem et al. measured CD126 expression on nPCs and aPCs in MGUS, SMM, and MM. CD126 was identified on all nPCs and aPCs. However, CD126 expression was higher in aPCs than in nPCs in $85 \%$ of SMM, but only $41 \%$ of MGUS. There was also a greater correlation between nPC and aPC CD126 expression in low-risk MGUS than described in high-risk MGUS and SMM, indicating a reduction in normal regulation of CD126 with disease transformation [123].

IL-12 concentrations seem to be altered in MM subjects compared to MGUS subjects.

A group of PB myeloid cells expressing the MDC8 antigen having a 6-sulfo LacNAc structure and named 6-sulfo LacNAc dendritic cells (Slan-DCs), has been reported. Slan-DCs form a tissue and circulating pro-inflammatory myeloid population which has been demonstrated to have a role in different tumor environments. Lamathee et al. investigated Slan-DCs in subjects with monoclonal gammopathies [124]. They executed functional research on the cells of newly diagnosed MM patients, MGUS subjects, and MM patients who responded to therapy. They observed that circulating Slan-DCs were considerably reduced in MM subjects compared to those of healthy controls or MGUS patients. Moreover, after activation by the TLR7/8 ligand R848, IL-12-producing Slan-DCs from the BM or $\mathrm{PB}$ from MM patients were reduced compared with healthy controls, and MM cells reduced the generation of IL-12 by Slan-DCs. Moreover, they modified the phenotype of Slan-DCs towards that of a monocyte-like phenotype. Lastly, they reported that Slan-DCs co-cultured with MM cells decreased their ability to cause T-cell growth and Th1 polarization.

IL-17, a disulfide-linked homodimer generated by activated memory T cells, is thought to be a mediator between the hematopoietic and immune systems, and promotes the production of IL-6 and Intercellular Adhesion Molecule (ICAM). The production of IL-17 in the BM of MM patients by T-helper lymphocytes is mediated by dendritic cells. Unlike in MGUS, the BM of MM patients contains a high number of Th-17-1 cells with the co-expression of 1L-17 and IFN- $\gamma$, interrelating with apoptotic myeloma elements [125]. However, in spite of these results, the study demonstrated no modifications in the serum concentrations between MGUS and MM.

Inflammation may affect the structure of both pc Ig and mc Ig produced by malignant plasma cells through the sialylation of Ig Fc fragments [87]. MGUS and MM subjects exhibiting hyposialylated pc IgGs had considerably greater concentrations of IL-33 compared to subjects with hypersialylated pc IgGs. In MGUS, as in MM, the hyposialylation of mc IgGs is concomitant with augmented concentrations of cytokines that have a central role in inflammation [87]. However, decreased IL-33 concentrations in MM subjects are associated with a more advanced stage of disease [126].

This result seems to be consistent with the evidence that a decrease of IL-33 might be implicated in T-cell alteration in hematological diseases [127].

Macrophages and monocytes can deliver inflammatory cytokines that increase the proliferation and survival of myeloma cells. Moreover, macrophages produce tumor necrosis factor $\alpha$ (TNF- $\alpha$ ), which can indirectly increase tumor proliferation $[128,129]$. In a study published some years ago, Bladè et al. reported that MGUS subjects with high concentrations of TNF- $\alpha$ had a greater probability of malignant progression than those with low serum concentrations [130].

Finally, although several studies have shown a different concentration of IL-16 in patients with MM, no study has evaluated cytokine concentrations in patients with MGUS [131]. 


\subsection{Anti-Inflammatory Cytokines}

The existence of a pro-inflammatory or anti-inflammatory action of IL-4 depends on the experimental conditions in which they are verified. The role of IL-4 in MM is also controversial. It can reduce IL-6 production and, consequently, plasma cell growth [132]. On the other hand, it also promotes the differentiation of PBNMCs into mature plasma cells, possibly because PBNMCs are not sensitive to IL-6 action $[133,134]$.

However, the activity of IL-4 on the differentiation of PBMNCs into mature plasma cells is more marked among cells from MM than MGUS patients.

Interleukin-10 is the most powerful B-cell differentiating factor, although it does not appear to operate on myeloma cells [135]. More recently, it has been demonstrated to promote the growth of myeloma cells in IL-6-deprived cultures. Therefore, it can be considered an IL-6-unrelated growth factor for myeloma plasma cells [136].

IL-10 concentration was evaluated in MGUS, in early or advanced stage MM, and in aggressive diseases. The highest number of subjects with measurable IL-10 was reported at early stages, as opposed to those with advanced or aggressive MM. IL-10 was not measurable in MGUS subjects. Thus, IL-10, like IL-6, may have a diagnostic value in differentiating MM from MGUS. However, unlike IL-6, high concentrations of IL-10 are associated with a better prognosis. Regrettably, no clinical studies have confirmed these data. In MM, the cytokine was detected at similar concentrations in all stages of the disease. Furthermore, IL-10 levels did not vary significantly between patients and healthy subjects, nor between MGUS subjects and MM patients [137].

IL-27 activity might differ according to the target cell type. However, IL-27 concentrations seem to be greater in MM subjects with active disease (MMECs) than in MGUS subjects.

Actually, IL-27 has been demonstrated to stimulate PD-L1 expression in several cell types, including $\mathrm{CD}^{+}$and $\mathrm{CD}^{+} \mathrm{T}$ cells, monocytes, DC, and tumor cells [138-140] Therefore, IL-27 might cause possible actions regulating the expression in MMECs of HLA-I, which downregulates NK cell activity, and also that of PD-L2, which regulates the level of both $\mathrm{CD}^{+} \mathrm{T}$ and NK cell activity. It has been demonstrated that in MM subjects, more than the 50\% of PB NK cells express PD-1, the PD-Ls receptor, although at concentrations lower than $\mathrm{PD}^{+}$in NK cells, as reported in healthy controls or in diverse diseases [141]. The ability of IL-27 to upregulate immune checkpoint ligands on tumor endothelium may significantly differ among patients. Remarkably, throughout the range of antitumor immune responses, IL-27 may operate earlier than IFN- $\gamma$, a factor delivered by innate cells such as macrophages and DCs.

Moreover, angiogenesis is characteristic of MM progression. Dondero et al. investigated the action of cytokine-stimulated NK cells against tumor-associated endothelial cells isolated from the BM aspirates of MM subjects with MMECs [142]. They demonstrated that NK cells stimulated with adequate doses of IL-15 destroyed MMECs via the activity of multiple activating receptors. In particular, according to the increased expression of Poliovirus receptor (PVR) and Nectin-2 on MMECs, DNAM-1 actively contributed to target detection. Remarkably, in MMECs, the density of PVR was considerably higher than that reported from MM subjects with MM in complete remission or with MGUS. Notably, IL-27, which unlike IL-15 does not show pro-angiogenic activities, augmented the NK cell functions provoked by suboptimal levels of IL-15.

A preliminary study reported substantially lower IGF-1 concentrations in MGUS and MM subjects compared with healthy controls, with the concentrations being significantly lower in MM than in MGUS [143]. However, in another study, IGF-1 concentrations were only occasionally higher in MGUS than in MM, with considerably higher concentrations in substage B.

Moreover, subjects with MM had drastically lower levels of serum transforming growth factor (TGF)- $\beta$ than subjects with MGUS [144].

Finally, the molecular chaperone heat shock protein interacts with several client proteins, either intracellular or cell-surface localized, which are functionally implicated in several essential regulatory 
pathways, such as cell cycle control and protection from apoptosis. Furthermore, its action appears to be indispensable for cancer cells in supporting abnormal homeostasis [145].

Small ubiquitin-like modifier (SUMO) belongs to a group of small proteins that modify the functions of target protein binding to amino acid residues [146-148]. Sumoylated proteins are implicated in several cellular mechanisms, including DNA damage response, response to stress, protein stability, transcriptional regulation, cell proliferation, and apoptosis [149-151].

Preuss et al. recognized a post-translationally-modified paraprotein target (paratargs) in MGUS and MM [152]. They reported that paraproteins from some subjects reacted with the sumoylated heat shock protein $90 \beta$ isoform- $\alpha$ (HSP90-SUMO1), while no effect was demonstrated in healthy controls. HSP90-SUMO1 was discovered in blood cells from all patients with HSP90-SUMO1-binding paraproteins. They established that the HSP90-SUMO1 carrier state is provoked by the incapacity of SUMO peptidase sentrin/SUMO-specific protease 2 (SENP2) to desumoylate HSP90-SUMO1. Although HSP90-SUMO1 was reported in a small percentage of controls, only MGUS and MM subjects who were HSP90-SUMO1 carriers produced HSP90-SUMO1-specific paraproteins, suggesting that sumoylated HSP90 contributes to the onset of these conditions (Figure 3).

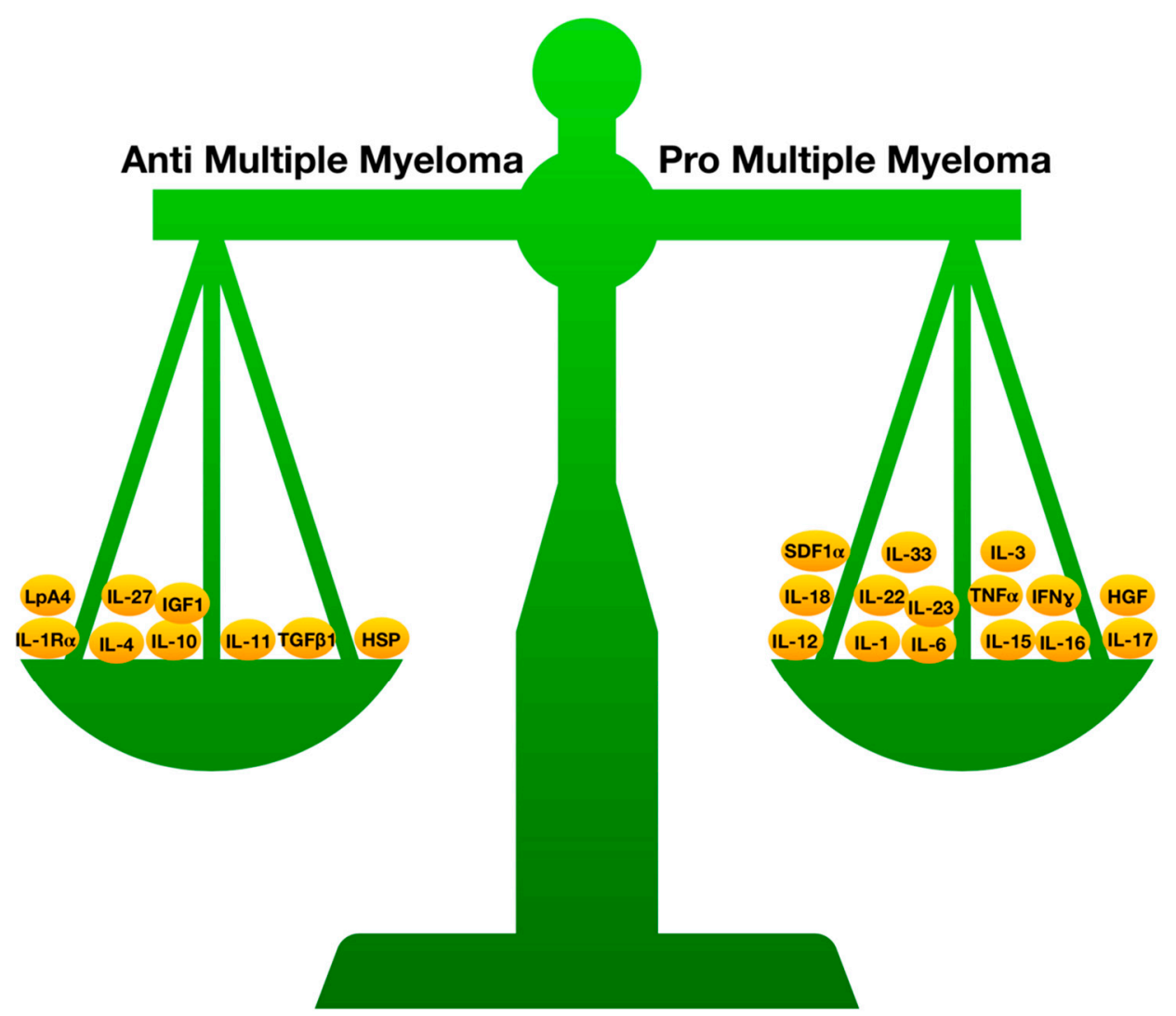

Figure 3. Balance of pro- and anti-inflammatory cytokines in multiple myeloma (MM) progression.

\section{Conclusions}

Almost all MM cases have been demonstrated to be linked to earlier MGUS. Nevertheless, no marker that would consistently foresee the onset of the two diseases with such different prognoses and therapeutic approaches is presently available in clinical practice (Table 1). 
Table 1. List of the most recent studies (2009-2019) concerning the monoclonal gammopathy of undetermined significance (MGUS) and multiple myeloma (MM) cytokine profiles. Values $+=$ molecules increased. Values $-=$ molecules decreased. BM $=$ bone marrow.

\begin{tabular}{|c|c|c|c|c|c|c|c|c|c|c|}
\hline Authors & Year & MGUS & MM & Humans & Animals & In Vivo & In Vitro & Ex Vivo & N. Pz. & Values \\
\hline Landgren O. et al. [10] & 2009 & $x$ & $\mathrm{x}$ & $\mathrm{x}$ & & $\mathrm{x}$ & & $\mathrm{x}$ & 71 & $+\mathrm{M}$ protein \\
\hline Chiecchio L. et al. [11] & 2009 & $x$ & $\mathrm{x}$ & $\mathrm{x}$ & & $x$ & & & 716 & +deletion/monosomy $13(\Delta 13)$ \\
\hline Garayoa M. et al. [76] & 2009 & & $\mathrm{x}$ & $\mathrm{x}$ & & & $\mathrm{x}$ & & 26 & distinct genomic profile \\
\hline Dezorella N. et al. [86] & 2009 & & $x$ & $\mathrm{x}$ & & BM & $\mathrm{x}$ & $\mathrm{x}$ & & -CD38; -CD138 \\
\hline Greco C. et al. [143] & 2009 & $\mathrm{x}$ & $x$ & $\mathrm{x}$ & & BM & $\mathrm{x}$ & $\mathrm{x}$ & 71 with MGUS; 77 with MM & -IGF-I \\
\hline Josselin N et al. [153] & 2009 & $\mathrm{x}$ & $\mathrm{x}$ & $\mathrm{x}$ & & $\mathrm{BM}$ & & $\mathrm{x}$ & 53 with MGUS; 46 with MM & +dendritic cells; +osteoclasts \\
\hline Racanelli V. et al. [52] & 2010 & $\mathrm{x}$ & $x$ & $\mathrm{x}$ & & $\mathrm{BM}$ & & $\mathrm{x}$ & 20 with MGUS; 20 with MM & $\mathrm{MM} \rightarrow \mathrm{APM}$ components \\
\hline Bonanno G. et al. [63] & 2012 & $x$ & $x$ & $\mathrm{x}$ & & $\mathrm{x}$ & $\mathrm{x}$ & & 7 with MGUS; 25 with MM & +IDO activity \\
\hline Wang P. et al. [13] & 2013 & $\mathrm{x}$ & $x$ & $x$ & & $\mathrm{BM}$ & $x$ & $x$ & 11 for MGUS; 13 for MM & $\begin{array}{l}\text { +BAFFR; +TACI; +BCMA in } \\
\text { MGUS; -BCMA in MM }\end{array}$ \\
\hline Mehtap O. et al. [80] & 2014 & & $x$ & $\mathrm{x}$ & & $\mathrm{BM}$ & & & 44 & $-\mathrm{IL}-21 ;+\mathrm{IL}-6,+\mathrm{IL}-1 \beta,+\mathrm{TNF}-\alpha$ \\
\hline Ferrucci A. et al. [88] & 2014 & $\mathrm{x}$ & $\mathrm{x}$ & $\mathrm{x}$ & & $\mathrm{BM}$ & $\mathrm{x}$ & & 24 with MGUS; 32 with MM & +HGF/cMET \\
\hline Feng P. et al. [60] & 2015 & & $\mathrm{x}$ & $\mathrm{x}$ & & $\mathrm{x}$ & & $x$ & 33 & $\begin{array}{l}\text { +Th1; +Th17; - } \mathrm{T}_{\text {reg; }}+\text { IL-6; } \\
\text { +IL17A; +IFN- } \gamma ;- \text {-Foxp3 }\end{array}$ \\
\hline Wang M. et al. [61] & 2015 & & $\mathrm{x}$ & $\mathrm{x}$ & & BM & & $\mathrm{x}$ & 55 & +Th17; +Th22 \\
\hline Di Lullo G. et al. [67] & 2015 & $x$ & $x$ & $\mathrm{x}$ & & $\mathrm{BM}$ & $x$ & $\mathrm{x}$ & 5 with MGUS; 37 with MM & +IL-13; +IL-17; +IL-22 \\
\hline Koerber R.M et al. [89] & 2015 & & $x$ & $\mathrm{x}$ & & & $\mathrm{x}$ & & & -Syk \\
\hline Nair S. et al. [6] & 2016 & $\mathrm{x}$ & $\mathrm{x}$ & $\mathrm{x}$ & $\mathrm{x}$ & $\mathrm{BM}$ & & $\mathrm{x}$ & $\begin{array}{c}20 \text { Gaucher's disease in } \\
\text { humans and } 6 \text { GBA } 1 \text { mice }\end{array}$ & +LGL1 \\
\hline Bosseboeuf A. et al. [5] & 2017 & $\mathrm{x}$ & $\mathrm{x}$ & $\mathrm{x}$ & & $\mathrm{x}$ & & $\mathrm{x}$ & 101 for MGUS; 135 for MM & $\begin{array}{c}+ \text { IL-6, + IL-10, +IL-33 in MGUS; } \\
\text {-IL-33 in MM }\end{array}$ \\
\hline McNee G. et al. [14] & 2017 & $\mathrm{x}$ & $\mathrm{x}$ & $\mathrm{x}$ & & $\mathrm{BM}$ & $\mathrm{x}$ & & 30 & +IL-6; +CXCL12; +cMET \\
\hline Bosseboeuf A. et al. [87] & 2017 & $x$ & $x$ & $x$ & & & & $\mathrm{x}$ & 68 with MGUS; 74 with MM & +IL-17, +IFN- $\alpha 2,+$ IL-33, + IL-13 \\
\hline Dondero A. et al. [142] & 2017 & $\mathrm{x}$ & $\mathrm{x}$ & $\mathrm{x}$ & & $\mathrm{BM}$ & $\mathrm{x}$ & & 9 & +NK; +IL-27 \\
\hline Salem D. et al. [123] & 2018 & $\mathrm{x}$ & $\mathrm{x}$ & $\mathrm{x}$ & & $\mathrm{BM}$ & & & 24 with MGUS; 35 with MM & $+\mathrm{CD} 126$ \\
\hline Lamarthée B. et al. [124] & 2018 & $x$ & $\mathrm{x}$ & $\mathrm{x}$ & & $\mathrm{BM}$ & $\mathrm{x}$ & & 21 with MGUS; 24 with MM & $\begin{array}{l}\text {-Slan-DC for MM; +Slan-DC for } \\
\text { MGUS; -IL-12 }\end{array}$ \\
\hline Nair S. et al. [7] & 2018 & $x$ & $\mathrm{x}$ & $\mathrm{x}$ & $x$ & $\mathrm{x}$ & & $\mathrm{x}$ & cohort 1 (76); cohort 2 (274) & $+\operatorname{Ig} \mathrm{G} ;+\mathrm{LPC}$ \\
\hline
\end{tabular}


Inflammatory cytokines are largely delivered in chronic hematological diseases, but the causes remain indeterminate and are likely to be multiple. Some cytokines may be generated by neoplastic cells as an effect of genetic mutations, but there is solid proof that cytokines are also delivered autonomously from gene mutations, both by clonal and non-clonal cells [154].

Therefore, cytokines can be used as therapeutic targets with several advantages. In fact, cytokines can be reduced, and cytokines are well-studied in animal experimental models employing genetic models such as knockout mice or neutralizing antibodies. On the contrary, emerging therapeutic attempts should not ignore the possible generation of a cytokine storm that might manipulate immune responses against myeloma cells and/or the tumor-associated microenvironment.

However, scientists should learn to recognize which cytokines have to be suppressed and which ones should be strengthened in an attempt to prevent the progression of MGUS into MM.

A model that predicts the negative action of pro-inflammatory proteins and the positive effect of anti-inflammatory proteins appears excessively simplistic and, as previously demonstrated for MM patients, completely inadequate [26].

Indeed, although several inflammatory cytokines appear to be reduced in patients with MGUS compared to those with MM (for example, IL-1, IL-2, IL-3, IL-17, and TNF), others appear to be increased (IL12) or equally expressed (IL-33). Similarly, anti-inflammatory cytokines seem to be both increased (TGF-1) and reduced (IL-4, IL-27, and IGF-1) in MGUS.

Proinflammatory cytokines are supposed to be essential for cancer progression, and anti-inflammatory drugs have been suggested to cure tumors. However, anti-inflammatory treatments may hypothetically decrease protective antitumor immunity. In fact, although inflammation is generally considered to be cancer-supporting, few reports in colorectal, breast, and bladder cancer indicate that tumor infiltration by inflammatory cells may be connected with an improved prognosis [155-157].

Pro-inflammatory cytokines can have both pro- and anticancer actions, while cytokines with strong anti-inflammatory action may strongly support the proliferation of cancer cells. To bring together these conflicting results, it is possible to propose that inflammation, when driven by tumor-specific Th1 cells, may stop tumor onset and progression. In a Th1 microenvironment, pro-inflammatory cytokines may participate in cancer eradication by attracting leucocytes from circulation and by augmenting $\mathrm{CD} 4^{+}$ T-cell action.

In the future, however, other aspects of the action of the immune system on the onset of gammopathies will have to be evaluated. In particular, special attention must be given to the action of alarmins and innate lymphoid cells (ILC).

Alarmins, such as high-mobility group box 1 (HMGB1) and S100 protein (S100), are a responsive set of proteins. They are produced as a result of cell injury, damage, or inflammation. They have several actions as they can trigger innate immunity and stimulate antigen-presenting cells (APCs), activating an adaptive response. However, they could alter homeostasis by causing an excessive pro-inflammatory response $[153,158]$.

The ILC family includes cytotoxic NK cells, ILC1, ILC2, ILC3, and lymphoid tissue inducer (LTi) cells $[159,160]$. These cells have critical roles in host defense and inflammation, representing the first-line defense against infection. ILCs present great correspondence with several T-cell subsets, suggesting that ILCs are the "innate" form of differentiated CD4 ${ }^{+}$and CD8 ${ }^{+} \mathrm{T}$ cells [161-164].

However, in patients with MGUS, interpretation of the role of lymphocyte populations and cytokines appears, in any case, to be more complex and difficult than in MM. In fact, any evaluation of the parameters appears static and inadequate in MGUS. Only longitudinal evaluation of the lymphocyte populations and the cytokine levels, assessed at different times and correlated with the eventual progression of the condition towards MM, will allow for the correct interpretation of data and development of an effective therapeutic approach.

In an age where the therapy of neoplastic monoclonal gammopathies largely relies on drugs capable of acting on the immune system (immunomodulants, immunological checkpoint inhibitors, CAR-T), detailed knowledge of the conditions existing in benign and neoplastic forms of gammopathy 
is the main foundation for the adequate and optimal use of new drugs. MM is accompanied by cellular immune defects, suggesting that transformation of the disease from a benign, precursor state is connected with an immunosuppressive milieu that promotes immune escape and tumor onset [165]. Nevertheless, the complexity of the BM microenvironment makes it difficult to develop efficacious immune therapies for MM. T cells have been demonstrated to be able to identify tumoral plasma cells (PCs), as demonstrated by the discovery of bone marrow-infiltrating T cells in MGUS capable of producing anti-PC immune responses. Moreover, the presence of immunity against plasma cell antigens is associated with delayed progression to MM. Nevertheless, once MM arises, bone marrow T-cell responses have not been described [166]. The rarity of antigen-specific $\mathrm{T}$ cells is one reason that immune checkpoint inhibitors such as anti-PD-1 have inadequate clinical efficacy in MM subjects [167]. Remarkably, lenalidomide seemed to have transitory efficacy after nivolumab during a phase where protracted receptor occupancy of the PD-1 receptor was imagined [168]. In view of the above, it might be interesting to hypothesize a study that attempts to prevent the progression of high-risk MGUS by using checkpoint inhibitors.

In this scenario, biologics represent a fascinating hope for the near future. Anakinra, the recombinant form of the IL-1 receptor antagonist (IL-1Ra), could be used for clinical studies of MGUS patients. IL-1Ra inhibits the binding of IL- $1 \alpha$ and IL-1 $\beta$ to IL-1R1. Even though anakinra is currently approved for the therapy of rheumatoid arthritis and cryopyrin-associated periodic syndromes [169], off-label employment of anakinra in several other diseases, and the theoretical possibility of intervening in the progression of MGUS, or even in the therapy of MM with the use of anakinra, certainly appears fascinating. Presently, there are very little data on this topic. However, this molecule has been positively employed for the treatment of complex disorders such as Schnitzler's syndrome, which is defined by monoclonal gammopathy (IgG or IgM) and a frequent urticaria rash, accompanying clinical symptoms of inflammation and an increased possibility of AA amyloidosis and lymphoproliferative diseases. These subjects are successfully treated with anakinra subcutaneously [170]. However, only the implementation of studies specifically designed to evaluate the effect of the inhibition of IL-1 with anakinra will be able to clarify the real role of cytokines in the onset and progression of MGUS.

To summarize, our review shows that the progression from MGUS to MM is a complex, and not yet completely clarified, process. Literature results have demonstrated that pro-inflammatory cytokines and important anti-inflammatory mediators, such as those represented in Figure 3, are fundamental. Their main function is in the regulation of immune system cells (CD4, CD8, Th17, Treg, Th22, ILC). These cytokines can have both pro- and anticancer actions, while cytokines with a strong anti-inflammatory action may strongly support the proliferation of cancer cells. This fragile balance, if disrupted, could favor MGUS progression to MM. Further studies should consider mediator levels in patients undergoing biologic treatments, in order to better clarify this delicate balance.

Author Contributions: Conceptualization, A.A., C.M., and S.G.; Data curation, V.I., A.G.A., and M.P.; Methodology, E.D.S.; Writing—original draft preparation, A.A. and E.D.S.; Writing-review and editing, A.A., C.M., and S.G.; Project administration, E.V.S. and S.G.; Funding acquisition, E.V.S.

Funding: This research received no external funding.

Conflicts of Interest: The authors declare no conflict of interest.

\section{References}

1. Kyle, R.A.; Rajkumar, S.V. Monoclonal gammopathies of undetermined significance. Hematol. Oncol. Clin. North Am. 1999, 13, 1181-1202. [CrossRef]

2. Weiss, B.M.; Abadie, J.; Verma, P.; Howard, R.S.; Kuehl, W.M. A monoclonal gammopathy precedes multiple myeloma in most patients. Blood 2009, 113, 5418-5422. [CrossRef] [PubMed]

3. Kyle, R.A. Multiple myeloma: How did it begin? Mayo Clin. Proc. 1994, 69, 680-683. [CrossRef]

4. Kyle, R.A. Monoclonal gammopathy of undetermined significance and solitary plasmacytoma. Implications for progression to overt multiple myeloma. Hematol. Oncol. Clin. North Am. 1997, 11, 71-87. [CrossRef] 
5. Bosseboeuf, A.; Feron, D.; Tallet, A.; Rossi, C.; Charlier, C.; Garderet, L.; Caillot, D.; Moreau, P.; Cardo-Vila, M.; Pasqualini, R.; et al. Monoclonal IgG in MGUS and multiple myeloma target infectious pathogens. J. Clin. Invest. Insight 2017, 2, 19. [CrossRef] [PubMed]

6. Nair, S.; Branagan, A.R.; Liu, J.; Boddupalli, C.S.; Mistry, P.K.; Dhodapkar, M.V. Clonal Immunoglobulin against Lysolipids in the Origin of Myeloma. N. Engl. J. Med. 2016, 374, 555-561. [CrossRef] [PubMed]

7. Nair, S.; Sng, J.; Sekhar Boddupalli, C.; Seckinger, A.; Chesi, M.; Fulciniti, M.; Zhang, L.; Rauniyar, N.; Lopez, M.; Neparidze, N.; et al. Antigen-mediated regulation in monoclonal gammopathies and myeloma. J. Clin. Invest. Insight 2018, 3, e98259. [CrossRef] [PubMed]

8. Sahota, S.S.; Leo, R.; Hamblin, T.J.; Stevenson, F.K. Ig VH gene mutational patterns indicate different tumor cell status in human myeloma and monoclonal gammopathy of undetermined significance. Blood 1996, 87, 746-755. [PubMed]

9. Drach, J.; Angerler, J.; Schuster, J.; Rothermundt, C.; Thalhammer, R.; Haas, O.A.; Jäger, U.; Fiegl, M.; Geissler, K.; Ludwig, H.; et al. Interphase fluorescence in situ hybridization identifies chromosomal abnormalities in plasma cells from patients with monoclonal gammopathy of undetermined significance. Blood 1995, 86, 3915-3921.

10. Landgren, O.; Kyle, R.A.; Pfeiffer, R.M.; Katzmann, J.A.; Caporaso, N.E.; Hayes, R.B.; Dispenzieri, A.; Kumar, S.; Clark, R.J.; Baris, D.; et al. Monoclonal gammopathy of undetermined significance (MGUS) consistently precedes multiple myeloma: A prospective study. Blood 2009, 113, 5412-5417. [CrossRef]

11. Chiecchio, L.; Dagrada, G.P.; Ibrahim, A.H.; Dachs Cabanas, E.; Protheroe, R.K.; Stockley, D.M.; Orchard, K.H.; Cross, N.C.; Harrison, C.J.; Ross, F.M.; et al. Timing of acquisition of deletion 13 in plasma cell dyscrasias is dependent on genetic context. Haematologica 2009, 94, 1708-1713. [CrossRef]

12. Landgren, $\mathrm{O}$. Monoclonal gammopathy of undetermined significance and smoldering multiple myeloma: Biological insights and early treatment strategies. Hematology 2013, 2013, 478-487. [CrossRef] [PubMed]

13. Wang, P.; Qian, L.; Yuan, X.; Hu, C.; Wang, L.; Huang, Q.; Miao, P.; Yu, Q.; Ma, Y.; Zhang, J.; et al. BlyS: A potential hallmark of multiple myeloma. Front. Biosci. Landmark 2013, 18, 324-331.

14. McNee, G.; Eales, K.L.; Wei, W.; Williams, D.S.; Barkhuizen, A.; Bartlett, D.B.; Essex, S.; Anandram, S.; Filer, A.; Moss, P.A.H.; et al. Citrullination of histone H3 drives IL-6 production by bone marrow mesenchymal stem cells in MGUS and multiple myeloma. Leukemia 2017, 31, 373-381. [CrossRef] [PubMed]

15. Van Riet, I.; Van Camp, B. The involvement of adhesion molecules in the biology of multiple myeloma. Leuk. Lymphoma 1993, 9, 441-452. [CrossRef] [PubMed]

16. Sonneveld, P.; Durie, B.G.; Lokhorst, H.M.; Frutiger, Y.; Schoester, M.; Vela, E.E. Analysis of multidrug-resistance (MDR-1) glycoprotein and CD56 expression to separate monoclonal gammopathy from multiple myeloma. Br. J. Haematol. 1993, 83, 63-67. [CrossRef] [PubMed]

17. Harada, H.; Kawano, M.M.; Huang, N.; Harada, Y.; Iwato, K.; Tanabe, O.; Tanaka, H.; Sakai, A.; Asaoku, H.; Kuramoto, A. Phenotypic difference of normal plasma cells from mature myeloma cells. Blood 1993, 81, 2658-2663. [PubMed]

18. San Miguel, J.F.; Almeida, J.; Ocqueteau, M. Detection of two subpopulations of plasma cells in MGUS patients: Utility in the differential diagnosis with multiple myeloma. Blood 1996, 88, 640a.

19. Hanahan, D.; Weinberg, R.A. Hallmarks of cancer: The next generation. Cell 2011, 144, 646-674. [CrossRef] [PubMed]

20. Sahota, S.S.; Leo, R.; Hamblin, T.J.; Stevenson, F.K. Myeloma VL and VH gene sequences reveal a complementary imprint of antigen selection in tumor cells. Blood 1997, 89, 219-226.

21. Yi, Q.; Osterborg, A. Idiotype-specific T cells in multiple myeloma: Targets for an immunotherapeutic intervention? Med. Oncol. 1996, 13, 1-7. [CrossRef] [PubMed]

22. Yi, Q.; Osterborg, A.; Bergenbrant, S.; Mellstedt, H.; Holm, G.; Lefvert, A.K. Idiotype-reactive T-cell subsets and tumor load in monoclonal gammopathies. Blood 1995, 86, 3043-3049. [PubMed]

23. Hong, S.; Qian, J.; Yang, J.; Li, H.; Kwak, L.W.; Yi, Q. Roles of idiotype-specific t cells in myeloma cell growth and survival: Th1 and CTL cells are tumoricidal while Th2 cells promote tumor growth. Cancer Res. 2008, 68, 8456-8464. [CrossRef] [PubMed]

24. Abdalla, A.O.; Hansson, L.; Eriksson, I.; Näsman-Glaser, B.; Rossmann, E.D.; Rabbani, H.; Mellstedt, H.; Osterborg, A. Idiotype protein vaccination in combination with adjuvant cytokines in patients with multiple myeloma-evaluation of T-cell responses by different read-out systems. Haematologica 2007, 92, 110-114. [CrossRef] [PubMed] 
25. Allegra, A.; Penna, G.; Innao, V.; Greve, B.; Maisano, V.; Russo, S.; Musolino, C. Vaccination of multiple myeloma: Current strategies and future prospects. Crit. Rev. Oncol. Hematol. 2015, 96, 339-354. [CrossRef] [PubMed]

26. Musolino, C.; Allegra, A.; Innao, V.; Allegra, A.G.; Pioggia, G.; Gangemi, S. Inflammatory and anti-inflammatory equilibrium, proliferative and anti-proliferative balance: The role of cytokines in multiple myeloma. Mediat. Inflamm. 2017. [CrossRef] [PubMed]

27. Pika, T.; Lochman, P.; Sandecka, V.; Maisnar, V.; Minarik, J.; Tichy, M.; Zapletalova, J.; Solcova, L.; Scudla, V.; Hajek, R. Immunoparesis in MGUS - Relationship of uninvolved immunoglobulin pair suppression and polyclonal immunoglobuline levels to MGUS risk categories. Neoplasma 2015, 62, 827-832. [CrossRef] [PubMed]

28. Magnano, L.; Fernández de Larrea, C.; Elena, M.; Cibeira, M.T.; Tovar, N.; Aróstegui, J.I.; Pedrosa, F.; Rosiñol, L.; Filella, X.; Yagüe, J.; et al. Prognostic Impact of Serum Heavy/Light Chain Pairs in Patients With Monoclonal Gammopathy of Undetermined Significance and Smoldering Myeloma: Long-Term Results From a Single Institution. Clin. Lymphoma Myeloma Leuk. 2016, 16, e71-e77. [CrossRef]

29. Cherry, B.M.; Costello, R.; Zingone, A.; Burris, J.; Korde, N.; Manasanch, E.; Kwok, M.; Annunziata, C.; Roschewski, M.J.; Engels, E.A.; et al. Immunoparesis and monoclonal gammopathy of undetermined significance are disassociated in advanced age. Am. J. Hematol. 2013, 88, 89-92. [CrossRef]

30. Valkovic, T.; Gacic, V.; Nacinovic-Duletic, A. Multiple Myeloma Index for Risk of Infection. J. Cancer 2018, 9 , 2211-2214.

31. Grigorieva, I.; Thomas, X.; Epstein, J. The bone marrow stromal environment is a major factor in myeloma cell resistance to dexamethasone. Exp. Hematol. 1998, 6, 597-603.

32. Nefedova, Y.; Landowski, T.H.; Dalton, W.S. Bone marrow stromal-derived soluble factors and direct cell contact contrib-ute to de novo drug resistance of myeloma cells by distinct mechanism. Leukemia 2003, 17, 1175-1182. [CrossRef] [PubMed]

33. Dhodapkar, M.V.; Krasovsky, J.; Olson, K.T. cells from the tumor microenvironment of patients with progressive myeloma can generate strong, tumor-specific cytolytic responses to autologous, tumor-loaded dendritic cells. Proc. Natl Acad. Sci. USA 2002, 99, 13009-13013. [CrossRef] [PubMed]

34. Dhodapkar, M.V.; Krasovsky, J.; Osman, K.; Geller, M.D. Vigorous premalignancy-specific effector T cell response in the bone marrow of patients with monoclonal gammopathy. J Exp Med. 2003, 11, 1753-1757. [CrossRef] [PubMed]

35. Lim, S.H.; Badros, A.; Lue, C.; Bartologie, N. Distinct T-cell clonal expansions in the vicinity of tumor cells in plasmacytoma. Cancer 2001, 91, 900-908. [CrossRef]

36. Raitakari, M.; Brown, R.D.; Gibson, J.; Joshua, D.E. T cells in myeloma. Hematol. Oncol. 2003, $21,33-42$. [CrossRef] [PubMed]

37. Moss, P.; Gillespie, G.; Frodsham, P.; Bell, J.; Reybrun, H. Clonal populations of CD4 and CD8 T cells in patients with multiple myeloma and paraproteinemia. Blood 1996, 8, 3297-3306.

38. Brown, R.D.; Yuen, E.; Nelson, M.; Gibson, J.; Joshua, D.E. The prognostic significance of T cell receptor $b$ gene rearrange-ments and idiotype-reactive T cells in multiple myeloma. Leukemia 1997, 11, 1312-1317. [CrossRef]

39. Sze, D.M.; Giesajtis, G.; Brown, R.D.; Raitakari, M.; Gibson, J.; Ho, J.; Baxter, A.G.; Fazekas de St Groth, B.; Basten, A.; Joshua, D.E. Clonal cytotoxic T cells are expanded in myeloma and reside in the CD8 ${ }^{+} \mathrm{CD} 57^{+} \mathrm{CD} 28^{-}$ compartment. Blood 2001, 98, 2817-2827. [CrossRef]

40. Kunzmann, V.; Bauer, E.; Feurle, J.; Weissinger, F.; Tony, P.; Wilheim, M. Stimulation of gammadelta T cells by aminophos-phonates and induction of antiplasma cell activity in mul-tiple myeloma. Blood 2000, 96, 384-392.

41. Davies, F.E.; Raje, N.; Hideshima, T.; Lentzsch, S.; Young, G.; Tai, Y.T.; Lin, B.; Podar, K.; Gupta, D.; Chauhan, D.; et al. Thalidomide and immunomodulatory derivatives augment natural killer cell cytotoxicity in multiple myeloma. Blood 2001, 98, 210-216. [CrossRef] [PubMed]

42. Hayashi, T.; Hideshima, T.; Akiyama, M.; Raje, N.; Richardson, P.; Chauhan, D.; Anderson, K.C. Ex vivo induction of multiple myeloma-specific cytotoxic T lymphocytes. Blood 2003, 102, 1435-1442. [CrossRef] [PubMed] 
43. Perez-Andres, M.; Almeida, J.; Martin-Ayuso, M.; Moro, M.J.; Martin-Nunez, G.; Galende, J.; Hernandez, J.; Mateo, G.; San Miguel, J.F.; Orfao, A. Characterization of Bone Marrow T Cells in Monoclonal Gammopathy of Undetermined Significance, Multiple Myeloma, and Plasma Cell Leukemia Demonstrates Increased Infiltration by Cytotoxic/Th1 T Cells Demonstrating a Squed TCR-V Repertoire. Cancer 2006, 106, 1296-1305. [CrossRef] [PubMed]

44. Ellis, T.M.; Le, P.T.; DeVries, G.; Stubbs, E.; Fisher, M.; Bhoopalam, N. Alterations in CD30 T Cells in Monoclonal Gammopathy of Undetermined Signicance. Clin. Immunol. 2001, 98, 301-307. [CrossRef] [PubMed]

45. Fonseca, R.; Bailey, R.J.; Ahmann, G.J.; Rajkumar, S.V.; Hoyer, J.D.; Lust, J.A.; Kyle, R.A.; Gertz, M.A.; Greipp, P.R.; Dewald, G.W. Genomic abnormalities in monoclonal gammopathy of undetermined significance. Blood 2002, 100, 1417-1424. [PubMed]

46. Kuehl, W.M.; Bergsagel, P.L. Multiple myeloma: Evolving genetic events and host interactions. Nat. Rev. Cancer 2002, 2, 175-187. [CrossRef] [PubMed]

47. Zhan, F.; Hardin, J.; Kordsmeier, B.; Bumm, K.; Zheng, M.; Tian, E.; Sanderson, R.; Yang, Y.; Wilson, C.; Zangari, M.; et al. Global gene expression profiling of multiple myeloma, monoclonal gammopathy of undetermined significance, and normal bone marrow plasma cells. Blood 2002, 99, 1745-1757. [CrossRef] [PubMed]

48. Dhodapkar, M.V.; Geller, M.D.; Chang, D.H.; Shimizu, K.; Fujii, S.; Dhodapkar, K.M.; Krasovsky, J. A reversible defect in natural killer T-cell function characterizes the progression of premalignant to malignant multiple myeloma. J. Exp. Med. 2003, 197, 1667-1676. [CrossRef]

49. Massaia, M.; Dianzani, U.; Bianchi, A.; Camponi, A.; Boccadoro, M.; Pileri, A. Defective generation of alloreactive cytotoxic T lymphocytes (CTL) in human monoclonal gammopathies. Clin. Exp. Immunol. 1988, 73, 214-218.

50. Choi, C.; Witzens, M.; Bucur, M.; Feuerer, M.; Sommerfeldt, N.; Trojan, A.; Ho, A.; Schirrmacher, V.; Goldschmidt, H.; Beckhove, P. Enrichment of functional CD8 memory T cells specific for MUC1 in bone marrow of patients with multiple myeloma. Blood 2005, 105, 2132-2134. [CrossRef]

51. Finn, O.J. Premalignant lesions as targets for cancer vaccines. J. Exp. Med. 2003, 198, 1623-1626. [CrossRef] [PubMed]

52. Racanelli, V.; Leone, P.; Frassanito, M.A.; Brunetti, C.; Perosa, F.; Ferrone, S.; Dammacco, F. Alterations in the antigen processing-presenting machinery of transformed plasma cells are associated with reduced recognition by CD8 T cells and characterize the progression of MGUS to multiple myeloma. Blood 2009. [CrossRef] [PubMed]

53. Tsung, K.; Meko, J.B.; Peplinski, G.R.; Tsung, Y.L.; Norton, J.A. IL-12 induces T helper-1 directed antitumor response. J. Immunol. 1997, 158, 3359-3365. [PubMed]

54. Nishioka, Y.; Hirao, M.; Robbins, P.D.; Lotze, M.T.; Tahara, H. Induction of systemic and therapeutic antitumor immunity using intratumoral injection of dendritic cells genetically modified to express interleukin. Cancer Res. 1999, 59, 4035-4041. [PubMed]

55. Nastala, C.L.; Edington, H.D.; McKinney, T.G.; Tahara, H.; Nalesnik, M.A.; Brunda, M.J.; Gately, M.K.; Wolf, S.F.; Schreiber, R.D.; Storkus, W.J. Recombinant IL-12 administration induces tumor regression in association with IFN-g production. J. Immunol. 1994, 153, 1697-1706. [PubMed]

56. Coughlin, C.M.; Salhany, K.E.; Wysocka, M.; Aruga, E.; Kurzawa, H.; Chang, A.E.; Hunter, C.A.; Fox, J.C.; Trinchieri, G.; Lee, W.M. Interleukin-12 and interleukin-18 synergistically induce murine tumor regression which involves inhibition of angiogenesis. J. Clin. Invest. 1998, 101, 1441-1452. [CrossRef] [PubMed]

57. Zhang, Y.; Song, L.X.; Zhang, X.; Xiao, C.; Chang, C.K. Function of peripheral blood Th17 cells in patients with multiple myeloma. Zhongguo Shi Yan Xue Ye Xue Za Zhi 2013, 21, 1187-1189. [PubMed]

58. Atanackovic, T.; Cao, Y.; Luetkens, T.; Panse, J.; Faltz, C.; Arfsten, J.; Bartels, K.; Wolschke, C.; Eiermann, T.; Zander, A.R.; et al. $\mathrm{CD}^{+} \mathrm{CD}^{2} 5^{+} \mathrm{FOXP}^{+} \mathrm{T}$ regulatory cells reconstitute and accumulate in the bone marrow of patients with multiple myeloma following allogeneic stem cell transplantation. Haematologica 2008, 3, 423-430. [CrossRef] [PubMed]

59. Prabhala, R.H.; Neri, P.; Bae, J.; Tassone, P.; Shammas, M.A.; Allam, C.K.; Daley, J.F.; Chauhan, D.; Blanchard, E.; Thatte, H.S.; et al. Dysfunctional T regulatory cells in multiple myeloma. Blood 2006, 1, 301-304. [CrossRef] [PubMed] 
60. Feng, P.; Yan, R.; Dai, X.; Xie, X.; Wen, H.; Yang, S. The alteration and clinical significance of h1/Th2/Th17/Treg cells in patients with multiple myeloma. Inflammation 2015, 38, 705-709. [CrossRef] [PubMed]

61. Wang, M.; Chen, P.; Jia, Y.; He, N.; Li, D.; Ji, C.; Ma, D. Elevated Th22 as well as Th17 cells associated with therapeutic outcome and clinical stage are potential targets in patients with multiple myeloma. Oncotarget 2015, 6, 17958-17967. [CrossRef] [PubMed]

62. Takikawa, O.; Yoshida, R.; Kido, R.; Hayaishi, O. Tryptophan degradation in mice initiated by indoleamine 2,3-dioxygenase. J. Biol. Chem. 1986, 261, 3648-3653. [PubMed]

63. Bonanno, G.; Mariotti, A.; Procoli, A.; Folgiero, V.; Natale, D.; De Rosa, L.; Majolino, I.; Novarese, L.; Rocci, A.; Gambella, M.; et al. Indoleamine 2,3-dioxygenase 1 (IDO1) activity correlates with immune system abnormalities in multiple myeloma. J. Transl. Med. 2012, 10, 247. [CrossRef] [PubMed]

64. Beyer, M.; Schultze, J.L. Regulatory T cells: Major players in the tumor microenvironment. Curr. Pharm. Design 2009, 15, 1879-1892. [CrossRef]

65. Beyer, M.; Classen, S.; Endl, E.; Kochanek, M.; Weihrauch, M.R.; Debey-Pascher, S.; Knolle, P.A.; Schultze, J.L. Comparative approach to define increased regulatory $\mathrm{T}$ cells in different cancer subtypes by combined assessment of CD127 and FOXP3. Clin. Dev. Immunol. 2011, 2011, 734036. [CrossRef] [PubMed]

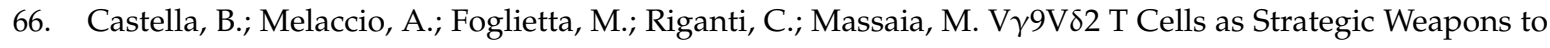
Improve the Potency of Immune Checkpoint Blockade and Immune Interventions in Human Myeloma. Front. Oncol. 2018, 8, 508. [CrossRef] [PubMed]

67. Di Lullo, G.; Marcatti, M.; Heltai, S.; Brunetto, E.; Tresoldi, C.; Bondanza, A.; Bonini, C.; Ponzoni, M.; Tonon, G.; Ciceri, F.; et al. Th22 cells increase in poor prognosis multiple myeloma and promote tumor cell growth and survival. Oncoimmunology 2015, 4, 1005460. [CrossRef]

68. Fridman, W.H.; Pages, F.; Sautes-Fridman, C.; Galon, J. The immune contexture in human tumours: Impact on clinical outcome. Nat. Rev. Cancer 2012, 12, 298-306. [CrossRef]

69. Protti, M.P.; Monte, L.D.; Lullo, G.D. Tumor antigen-specific CD4(+) T cells in cancer immunity: From antigen identification to tumor prognosis and development of therapeutic strategies. Tissue Antigens 2014, 83, 237-246. [CrossRef]

70. Galon, J.; Costes, A.; Sanchez-Cabo, F.; Kirilovsky, A.; Mlecnik, B.; Lagorce-Pages, C.; Tosolini, M.; Camus, M.; Berger, A.; Wind, P.; et al. Type, density, and location of immune cells within human colorectal tumors predict clinical outcome. Science 2006, 313, 1960-1964. [CrossRef]

71. Garderet, L.; Mazurier, C.; Chapel, A.; Ernou, I.; Boutin, L.; Holy, X.; Gorin, N.C.; Lopez, M.; Doucet, C.; Lataillade, J.J. Mesenchymal stem cell abnormalities in patients with multiple myeloma. Leuk. Lymphoma 2007, 48, 2032-2041. [CrossRef] [PubMed]

72. Wallace, S.R.; Oken, M.M.; Lunetta, K.L.; Panoskaltsis-Mortari, A.; Masellis, A.M. Abnormalities of bone marrow mesenchymal cells in multiple myeloma patients. Cancer 2001, 91, 1219-1230. [CrossRef]

73. Zdzisinska, B.; Bojarska-Junak, A.; Dmoszynska, A.; Kandefer-Szerszen, M. Abnormal cytokine production by bone marrow stromal cells of multiple myeloma patients in response to RPMI8226 myeloma cells. Arch. Immunol. Ther. Exp. 2008, 56, 207-221. [CrossRef] [PubMed]

74. Arnulf, B.; Lecourt, S.; Soulier, J.; Ternaux, B.; Lacassagne, M.N.; Crinquette, A.; Dessoly, J.; Sciaini, A.K.; Benbunan, M.; Chomienne, C.; et al. Phenotypic and functional characterization of bone marrow mesenchymal stem cells derived from patients with multiple myeloma. Leukemia 2007, 21, 158-163. [CrossRef] [PubMed]

75. Corre, J.; Mahtouk, K.; Attal, M.; Gadelorge, M.; Huynh, A.; Fleury-Cappellesso, S.; Danho, C.; Laharrague, P.; Klein, B.; Rème, T.; et al. Bone marrow mesenchymal stem cells are abnormal in multiple myeloma. Leukemia 2007, 21, 1079-1088. [CrossRef] [PubMed]

76. Garayoa, M.; Garcia, J.L.; Santamaria, C.; Garcia-Gomez, A.; Blanco, J.F.; Pandiella, A.; Hernández, J.M.; Sanchez-Guijo, F.M.; del Cañizo, M.C.; Gutiérrez, N.C.; et al. Mesenchymal stem cells from multiple myeloma patients display distinct genomic profile as compared with those from normal donors. Leukemia 2009, 23, 1515-1527. [CrossRef] [PubMed]

77. Chen, H.; Campbell, R.A.; Chang, Y.; Li, M.; Wang, C.S.; Li, J.; Sanchez, E.; Share, M.; Steinberg, J.; Berenson, A.; et al. Pleiotrophin produced by multiple myeloma induces transdifferentiation of monocytes into vascular endothelial cells: A novel mechanism of tumor-induced vasculo-genesis. Blood 2009, 113, 1992-2002. [CrossRef] 
78. Sponaas, A.M.; Moen, S.H.; Liabakk, N.B.; Feyzi, E.; Holien, T.; Kvam, S.; Grøseth, L.A.; Størdal, B.; Buene, G.; Espevik, T.; et al. The proportion of CD16(C)CD14(dim) monocytes increases with tumor cell load in bone marrow of patients with multiple myeloma. Immun. Inflamm. Dis. 2015, 3, 94-102. [CrossRef]

79. Sedlarikova, L.; Sadilkova, K.; Kubiczkova, L.; Hajek, R.; Sevcikova, S. Citokines profiles of multiple myeloma and Waldenstrom macroglobulinemia. Klin. Oncol. 2014, 27, 18-23. [CrossRef]

80. Mehtap, O.; Atesoglu, E.B.; Tarkun, A.; Hacihanefioglu, A.; Dolasik, I.; Musul, M.M. IL-21 and other serum proinflammatory cytokine levels in patients with multiple myeloma at diagnosis. J. Postgrad Med. 2014, 60, 141-144. [CrossRef]

81. Owagara, H.; Handa, H.; Yamazaki, T.; Toda, T.; Yoshida, K.; Nishimoto, N.; Al-ma'Quol, W.H.; Kaneko, Y.; Matsushima, T.; Tsukamoto, N.; et al. High Th1/Th2 ratio in patients with multiple myeloma. Leuk Res. 2005, 29, 135-140. [CrossRef] [PubMed]

82. Hideshima, T.; Chauhan, D.; Hayashi, T.; Podar, K.; Akiyama, M.; Gupta, D.; Richardson, P.; Munshi, N.; Anderson, K.C. The biological sequelae of stromal cell-derived factor-1alpha in multiple myeloma. Mol. Cancer Ther. 2002, 1, 539-544. [PubMed]

83. Podar, K.; Tai, Y.T.; Davies, F.E.; Lentzsch, S.; Sattler, M.; Hideshima, T.; Lin, B.K.; Gupta, D.; Shima, Y.; Chauhan, D.; et al. Vascular endothelial growth factor triggers signalling cascades mediating multiple myeloma cell growth and migration. Blood 2001, 98, 428-435. [CrossRef]

84. Derksen, P.W.; de Gorter, D.J.; Meijer, H.P.; Bende, R.J.; van Dijk, M.; Lokhorst, H.M.; Bloem, A.C.; Spaargaren, M.; Pals, S.T. The hepatocyte growth factor/Met pathway controls proliferation and apoptosis in multiple myeloma. Leukemia 2003, 17, 764-774. [CrossRef] [PubMed]

85. Cheung, W.C.; Van Ness, B. Distinct IL-6 signal transduction leads to growth arrest and death in B cells or growth promotion and cell survival in myeloma cells. Leukemia 2002, 16, 1182-1188. [CrossRef]

86. Dezorella, N.; Pevsner-Fischer, M.; Deutsch, V.; Kay, S.; Baron, S.; Stern, R.; Tavor, S.; Nagler, A.; Naparstek, E.; Zipori, D.; et al. Mesenchymal stromal cells revert multiple myeloma cells to less differentiated phenotype by the combined activities of adhesive interactions and interleukin-6. Exp. Cell Res. 2009, 315, 1904-1913. [CrossRef] [PubMed]

87. Bosseboeuf, A.; Allain-Maillet, S.; Mennesson, N.; Tallet, A.; Rossi, C.; Garderet, L.; Caillot, D.; Moreau, P.; Piver, E.; Girodon, F.; et al. Pro-inflammatory State in Monoclonal Gammopathy of Undetermined Significance and in Multiple Myeloma Is haracterized by Low Sialylation of Pathogen-Specific and Other Monoclonal Immunoglobulins. Front. Immunol. 2017, 8, 1347. [CrossRef] [PubMed]

88. Ferrucci, A.; Moschetta, M.; Frassanito, M.A.; Berardi, S.; Catacchio, I.; Ria, R.; Racanelli, V.; Caivano, A.; Solimando, A.G.; Vergara, D.; et al. A HGF/cMET autocrine loop is operative in multiple myeloma bone marrow endothelial cells and may represent a novel therapeutic target. Clin. Cancer Res. 2014, 205, 796-807. [CrossRef]

89. Koerber, R.M.; Held, S.A.E.; Heine, A.; Kotthoff, P.; Daecke, S.N.; Bringmann, A.; Brossart, P. Analysis of the anti-proliferative and the pro-apoptotic efficacy of Syk inhibition in multiple myeloma. Exp. Hematol. Oncol. 2015, 4, 21. [CrossRef]

90. Westendorf, J.J.; Ahmann, G.J.; Greipp, P.R.; Witzig, T.E.; Kyle, R.A.; Lust, J.A.; Jelinek, D.F. Establishment and characterization of three myeloma cell lines that demonstrate variable cytokine responses and abilities to produce autocrine interleukin. Leukemia 1996, 10, 866-876. [PubMed]

91. Lichtenstein, A.; Berenson, J.; Norman, D.; Chang, M.P.; Carlile, A. Production of cytokines by bone marrow cells obtained from patients with multiple myeloma. Blood 1989, 74, 1266-1273. [PubMed]

92. Klein, B.; Lu, Z.Y.; Gaillard, J.P.; Harousseau, J.L.; Bataille, R. Inhibiting IL-6 in human multiple myeloma. Curr. Top. Microbiol. Immunol. 1992, 182, 237-244. [PubMed]

93. Cozzolino, F.; Torcia, M.; Aldinucci, D.; Rubartelli, A.; Miliani, A.; Shaw, A.R.; Lansdorp, P.M.; Di Guglielmo, R. Production of interleukin-1 by bone marrow myeloma cells. Blood 1989, 74, 380-387. [PubMed]

94. Donovan, K.A.; Lacy, M.Q.; Kline, M.P. Contrast in cytokine expression between patients with monoclonal gammopathy of undetermined significance or multiple myeloma. Leukemia 1998, 12, 593-600. [CrossRef] [PubMed]

95. Kyle, R.A.; Lust, J.A. Monoclonal gammopathies of undetermined significance. Semin. Hematol. 1989, 26, 176-200. [PubMed] 
96. Hawley, T.S.; Lach, B.; Burns, B.F.; May, L.T.; Sehgal, P.B.; Hawley, R.G. Expression of retrovirally transduced IL-1alpha in IL-6-dependent B cells: A murine model of aggressive multiple myeloma. Growth Factors. 1991, 5, 327-338. [CrossRef]

97. Hawley, R.G.; Wang, M.H.; Fong, A.Z.; Hawley, T.S. Association between ICAM-1 expression and metastatic capacity of murine B-cell hybridomas. Clin. Exp. Metastasis 1993, 11, 213-226. [CrossRef]

98. Hamilton, M.S.; Ball, J.; Bromidge, E.; Franklin, I.M. Surface antigen expression of human neoplastic plasma cells includes molecules associated with lymphocyte recirculation and adhesion. Br. J. Haematol. 1991, 78, 60-65. [CrossRef]

99. Van Camp, B.; Durie, B.G.; Spier, C.; De Waele, M.; Van Riet, I.; Vela, E.; Frutiger, Y.; Richter, L.; Grogan, T.M. Plasma cells in multiple myeloma express a natural killer cell-associated antigen: CD56 (NKH-1; Leu-19). Blood 1990, 6, 377-382.

100. Lewinsohn, D.M.; Nagler, A.; Ginzton, N.; Greenberg, P.; Butcher, E.C. Hematopoietic progenitor cell expression of the H-CAM (CD44) homing-associated adhesion molecule. Blood 1990, 75, 589-595.

101. Drach, J.; Gattringer, C.; Huber, H. Expression of the neural cell adhesion molecule (CD56) by human myeloma cells. Clin. Exp. Immunol. 1991, 83, 418-422. [CrossRef]

102. Dinarello, C.A. Biologic basis for interleukin-1 in disease. Blood 1996, 87, 2095-2147.

103. Rettig, M.B.; Ma, H.J.; Vescio, R.A.; Põld, M.; Schiller, G.; Belson, D.; Savage, A.; Nishikubo, C.; Wu, C.; Fraser, J.; et al. Kaposi's sarcoma-associated herpesvirus infection of bone marrow dendritic cells from multiple myeloma patients. Science 1997, 276, 1851-1854. [CrossRef]

104. Corley, P.A. Induction of interleukin-1 and glucocorticoid hormones by HIV promotes viral replication and links human chromosome 2 to AIDS pathogenesis: Genetic mechanisms and therapeutic implications. Med. Hypotheses 1997, 48, 415-421. [CrossRef]

105. Beaulieu, A.D.; Paquin, R.; Gosselin, J. Epstein-Barr virus modulates de novo protein synthesis in human neutrophils. Blood 1995, 86, 2789-2798. [PubMed]

106. Bitko, V.; Velazquez, A.; Yang, L.; Yang, Y.C.; Barik, S. Transcriptional induction of multiple cytokines by human respiratory syncytial virus requires activation of NF-kappa B and is inhibited by sodium salicylate and aspirin. Virology 1997, 232, 369-378. [CrossRef] [PubMed]

107. Vacca, R.; Di Stefano, A.; Frassanito, G.; Iodice, A.; Dammacco, F. A disturbance of the IL-2/IL-2 receptor system parallels the activity of multiple myeloma. Clin. Exp. Immunol. 1991, 84, 429-443.

108. Goto, H.; Shimazaki, C.; Ashikara, E.; Ohkawa, K.; Oku, N.; Inaba, T.; Murakami, S.; Fujita, S.; Nakagawa, M. Effects of interleukin-3 and interleukin- 6 on peripheral blood cells from mul-tiple myeloma patients and their clinical significance. Acta Haematol. 1992, 88, 129-135. [CrossRef]

109. Treon, S.P.; Anderson, K.C. Interleukin-6 in multiple myeloma and related plasma cell dyscrasias. Curr. Opin. Haem. 1998, 5, 42-48. [CrossRef]

110. Teoh, G.; Anderson, K.C. Interaction of tumor and host cells with adhesion and extracellular matrix molecules in the development of multiple myeloma. Hematol Oncol Clin North Am. 1997, 11, 27-42. [CrossRef]

111. Chauhan, D.; Uchiyama, H.; Akbarali, Y.; Urashima, D.; Yamamoto, K.I.; Libermann, T.A.; Anderson, K.C. Multiple myeloma cell adhesion induced interleukin- 6 expression in bone marrow stromal cells involves activation of NF-kB. Blood 1996, 87, 1104-1112. [PubMed]

112. Lokhorst, H.M.; Lemme, T.; De Smet, M.; Klein, S.; De Weger, R.A.; Van Oers, R.; Bloem, A.C. Primary tumor cells of myeloma patients induce interleukin-6 secretion in long-term bone marrow cultures. Blood 1994, 84, 2269-2277. [PubMed]

113. Frassanito, M.A.; Cusmai, A.; Dammacco, F. Deregulated cytokine network and defective Th1 immune response in multiple myeloma. Clin. Exp. Immunol. 2001, 125, 190-197. [CrossRef] [PubMed]

114. Nachbaur, D.M.; Herold, M.; Maneschg, A.; Huber, H. Serum levels of interleukin 6 in multiple myeloma and other hematological disorders: Correlation with disease activity and other prognostic parameters. Ann. Haematol. 1991, 62, 54-58. [CrossRef]

115. Duvillard, L.; Guiguet, M.; Casanovas, R.O.; Caillot, D.; Monnier-Zeller, V.; Bernard, A.; Guy, H.; Solary, E. Diagnostic value of serum interleukin 6 levels in monoclonal gammopathies. Br. J. Haematol. 1995, 89, 243-249. [CrossRef] [PubMed] 
116. Bataille, R.; Jourdan, M.; Zhang, X.G.; Klein, B. Serum levels of interleukin 6, a potent myeloma cell growth factor, as a reflect of disease severity in plasma cell dyscrasias. J. Clin. Investig. 1989, 84, 2008-2011. [CrossRef]

117. Papadaki, H.; Kyriakou, D.; Foudoulakis, A.; Markidou, F.; Alexandrakis, M.; Eliopoulos, G.D. Serum levels of soluble IL-6 receptor in multiple myeloma as indicator of disease activity. Acta Haematol. 1997, 97, 191-195. [CrossRef]

118. Soutar, R.L.; Dillon, J.M.; Brown, D.; Ralston, S.H. Cytokine expression in multiple myeloma and monoclonal gammopathy: Analysis by reverse transcription/polymerase chain reaction and quantitation PCR. Leuk. Lymphoma 1996, 24, 111-120. [CrossRef]

119. Emile, C.; Fermand, J.P.; Danon, F. Interleukin-6 serum levels in patients with multiple myeloma. Br. J. Haematol. 1994, 86, 439-440. [CrossRef]

120. Blade, J.; Filella, X.; Montoto, S.; Bosch, F.; Rosinol, L.; Coca, F.; Gine, E.; Nadal, E.; Aymerich, M.; Rozman, M.; et al. Interleukin 6 and tumour necrosis factor alpha serum levels in monoclonal gammopathy of undetermined significance. Br. J. Haematol. 2002, 117, 387-389. [CrossRef]

121. Stasi, R.; Brunetti, M.; Parma, A.; Di Giulio, C.; Terzoli, E.; Pagano, A. The prognostic value of soluble interleukin-6 receptor in patients with multiple myeloma. Cancer 1998, 82, 1860-1866. [CrossRef]

122. Gaillard, J.P.; Bataille, R.; Brailly, H.; Zuber, C.; Yasukawa, K.; Attal, M.; Maruo, N.; Taga, T.; Kishimoto, T.; Klein, B. Increased and highly stable levels of functional soluble interleukin-6 receptor in sera of patients with monoclonal gammopathy. Eur. J. Immunol. 1993, 23, 820-824. [CrossRef] [PubMed]

123. Salem, D.A.; Korde, N.; Venzon, D.J.; Liewehr, D.J.; Maric, I.; Calvo, K.R.; Braylan, R.; Tembhare, P.R.; Yuan, C.M.; Landgren, C.O.; et al. Expression of the IL-6 receptor alpha-chain (CD126) in normal and abnormal plasma cells in monoclonal gammopathy of undetermined significance and smoldering myeloma. Leuk. Lymphoma 2018, 59, 178-186. [CrossRef] [PubMed]

124. Lamarthée, B.; de Vassoigne, F.; Malard, F.; Stocker, N.; Boussen, I.; Médiavilla, C.; Tang, R.; Fava, F.; Garderet, L.; Marjanovic, Z.; et al. Quantitative and functional alterations of 6-sulfo LacNac dendritic cells in multiple myeloma. OncoImmunology 2018, 7, 7.

125. Dhodapkar, K.M.; Barbuto, S.; Matthews, P.; Kukreja, A.; Mazumder, A.; Vesole, D.; Jagannath, S.; Dhodapkar, M.V. Dendritic cells mediate the induction of polyfunctional human IL17-producing cells (Th17-1 cells) enriched in the bone marrow of patients with myeloma. Blood 2008, 112, 2878-2885. [CrossRef] [PubMed]

126. Musolino, C.; Allegra, A.; Profita, M.; Alonci, A.; Saitta, S.; Russo, S.; Bonanno, A.; Innao, V.; Gangemi, S. Reduced IL-33 plasma levels in multiple myeloma patients are associated with more advanced stage of disease. Br. J. Haematol. 2013, 160, 709-710. [CrossRef] [PubMed]

127. Musolino, C.; Allegra, A.; Profita, M.; Alonci, A.; Saitta, S.; Bonanno, A.; Gerace, D.; Calabrò, L.; Gangemi, S. Reduction in IL-33 plasma levels might be involved in T cell dysregulation in chronic lymphocytic leukemia. Acta Haematol. 2014, 131, 165-166. [CrossRef] [PubMed]

128. Bianchi, G.; Munshi, N.C. Pathogenesis beyond the cancer clone(s) in multiple myeloma. Blood 2015, 125, 3049-3058. [CrossRef] [PubMed]

129. Roussou, M.; Tasidou, A.; Dimopoulos, M.A.; Kastritis, E.; Migkou, M.; Christoulas, D.; Gavriatopoulou, M.; Zagouri, F.; Matsouka, C.; Anagnostou, D.; et al. Increased expression of macrophage inflammatory protein-1 alpha on trephine biopsies correlates with extensive bone disease, increased angiogenesis and advanced stage in newly diagnosed patients with multiple myeloma. Leukemia 2009, 23, 2177-2181. [CrossRef] [PubMed]

130. Bladè, J.; Filella, X.; Montoto, S.; Bosch, F.; Molina, R.; Coca, F.; Lopez-Guillermo, A.; Cid, J.; Ballesta, A.; Montserrat, E. Clinical relevance of interleukin 6 and tumor necrosis factor-alpha serum levels in monoclonal gammopathy of undetermined significance. Blood 1997, 90, 351.

131. Allegra, A.; Alonci, A.; Bellomo, G.; Granata, A.; Tolomeo, A.; Penna, G.; Russo, S.; Sabattini, E.; Musolino, C. Serum levels of interleukin-16 in a multiple myeloma patient with cutaneous involvement. Int. J. Derm. 2010, 49, 435-437. [CrossRef] [PubMed]

132. Hermann, F.; Andreeff, M.; Gruss, H.J.; Brach, M.A.; Lubbert, M.; Mertelsmann, R. Interleukin-4 inhibits growth of multiple myelomas by suppressing interleukin-6 expression. Blood 1991, 78, 2070-2074.

133. Sawamura, M.; Murakami, H.; Tamura, J.; Matsushima, T.; Sato, S.; Naruse, T.; Tsuchiya, J. Tumor necrosis factor- and interleukin-4 promote the differentiation of myeloma cell precursors in multiple myeloma. Br. J. Haematol. 1994, 88, 17-23. [CrossRef] [PubMed] 
134. Sawamura, M.; Murakami, H.; Tsuchiya, J. Tumor necrosis factor- and interleukin-4 in myeloma cell precursor differentiation. Leuk. Lymph. 1996, 21, 31-36. [CrossRef] [PubMed]

135. Banchereau, J.; Rousset, F. Human B lymphocytes: Phenotype, proliferation and differentiation. Adv. Immunol. 1992, 52, 125-130. [PubMed]

136. Merico, F.; Bergui, L.; Gregoretti, M.G.; Ghia, P.; Aimo, G.; Lindley, I.J.O.; Caligaris-Cappio, F. Cytokines involved in the progression of multiple myeloma. Clin. Exp. Immunol. 1993, 92, 27-31. [CrossRef] [PubMed]

137. Stasi, R.; Brunetti, M.; Bussa, S.; Pagano, A. Serum interleukin-10 in plasma cell dyscrasias. Am. J. Hematol. 1997, 54, 335-337. [CrossRef]

138. Yoshida, H.; Hunter, C.A. The immunobiology of interleukin. Annu. Rev. Immunol. 2015, 33, 417-443. [CrossRef] [PubMed]

139. Murugaiyan, G.; Saha, B. IL-27 in tumor immunity and immunotherapy. Trends Mol. Med. 2013, 19, $108-116$. [CrossRef] [PubMed]

140. Carbotti, G.; Barisione, G.; Airoldi, I.; Mezzanzanica, D.; Bagnoli, M.; Ferrero, S.; Petretto, A.; Fabbi, M.; Ferrini, S. IL-27 induces the expression of IDO and PD-L1 in human cancer cells. Oncotarget 2015, 6, 43267-43280. [CrossRef]

141. Pesce, S.; Greppi, M.; Tabellini, G.; Rampinelli, F.; Parolini, S.; Olive, D.; Moretta, L.; Moretta, A.; Marcenaro, E. Identification of a subset of human natural killer cells expressing high levels of programmed death 1 : A phenotypic and functional characterization. J. Allergy Clin. Immunol. 2017, 139, 335-346. [CrossRef] [PubMed]

142. Dondero, A.; Casu, B.; Bellora, F.; Vacca, A.; De Luisi, A.; Frassanito, M.A.; Cantoni, C.; Gaggero, S.; Olive, D.; Moretta, A.; et al. NK cells and multiple myeloma-associated endothelial cells: Molecular interactions and influence of IL-27. Oncotarget 2017, 8, 35088-35102. [CrossRef] [PubMed]

143. Greco, C.; Vitelli, G.; Vercillo, G.; Vona, R.; Giannarelli, D.; Sperduti, I.; Pisani, F.; Capoluongo, E.; Petti, M.C.; Ameglio, F. Reduction of serum IGF-1 levels in patients affected with monoclonal gammopathies of undetermined significance or multiple myeloma. Comparison with bFGF, VEGF and k-ras gene mutation. J. Exp. Clin. Cancer Res. 2009, 28, 35. [CrossRef] [PubMed]

144. Diamond, T.; Levy, A.; Smith, A.; Day, P.; Manoharan, A. Non-invasive markers of bone turnover and plasma cytokines differ in osteoporotic patients with multiple myeloma and monoclonal gammopathies of undetermined significance. Intern. Med. J. 2001, 31, 272-278. [CrossRef] [PubMed]

145. Allegra, A.; Sant'antonio, E.; Penna, G.; Alonci, A.; D’Angelo, A.; Russo, S.; Cannavò, A.; Gerace, D.; Musolino, C. Novel therapeutic strategies in multiple myeloma: Role of the heat shock protein inhibitors. Eur. J. Haematol. 2011, 86, 93-110. [CrossRef] [PubMed]

146. Pinder, J.B.; Attwood, K.M.; Dellaire, G. Reading, writing, and repair: The role of ubiquitin and the ubiquitin-like proteins in DNA damage signaling and repair. Front. Genet. 2013, 4, 45. [CrossRef]

147. Bologna, S.; Ferrari, S. It takes two to tango: Ubiquitin and SUMO in the DNA damage response. Front. Genet. 2013, 4, 106. [CrossRef] [PubMed]

148. Al-Hakim, A.; Escribano-Diaz, C.; Landry, M.C.; O’Donnell, L.; Panier, S.; Szilard, R.K.; Durocher, D. The ubiquitous role of ubiquitin in the DNA damage response. DNA Repair 2010, 9, 1229-1240. [CrossRef]

149. Matunis, M.J.; Coutavas, E.; Blobel, G. A novel ubiq-uitin-like modification modulates the partition-ing of the Ran-GTPase-activating protein Ran-GAP1 between the cytosol and the nuclear pore complex. J. Cell Biol. 1996, 135, 1457-1470. [CrossRef]

150. Mahajan, R.; Delphin, C.; Guan, T.; Gerace, L.; Melchior, F. A small ubiquitin-related polypeptide involved in targeting RanGAP1 to nuclear pore complex protein Ranbp. Cell 1997, 88, 97-107. [CrossRef]

151. Janka, C.; Selmi, C.; Gershwin, M.E.; Will, H.; Sternsdorf, T. Small ubiquitin-related modifiers: A novel and independent class of autoantigens in primary biliary cirrhosis. Hepatology 2005, 41, 609-616. [CrossRef] [PubMed]

152. Preuss, K.D.; Pfreundschuh, M.; Fadle, N.; Regitz, E.; Kubuschok, B. Sumoylated HSP90 is a dominantly inherited plasma cell dyscrasias risk factor. J. Clin. Invest. 2015, 125, 316-323. [CrossRef] [PubMed]

153. Josselin, N.; Libouban, H.; Dib, M.; Ifrah, N.; Legrand, E.; Baslé, M.F.; Audran, M.; Chappard, D. Quantification of dendritic cells and osteoclasts in the bone marrow of patients with monoclonal gammopathy. Pathol. Oncol. Res. 2009, 15, 65-72. [CrossRef] [PubMed]

154. Boissinot, M.; Vilaine, M.; Hermouet, S. The hepatocyte growth factor (HGF)/ met axis: A neglected target in the treatment of chronic myeloproliferative neoplasms? Cancers 2014, 6, 1631-1669. [CrossRef] [PubMed] 
155. Klintrup, K.; Mäkinen, J.M.; Kauppila, S.; Väre, P.O.; Melkko, J.; Tuominen, H.; Tuppurainen, K.; Mäkelä, J.; Karttunen, T.J.; Mäkinen, M.J. Inflammation and prognosis in colorectal cancer. Eur. J. Cancer 2005, 41, 2645-2654. [CrossRef] [PubMed]

156. Lee, A.H.; Gillett, E.C.; Ryder, K.; Fentiman, I.S.; Miles, D.W.; Millis, R.R. Different patterns of inflammation and prognosis in invasive carcinoma of the breast. Histopathology 2006, 48, 692-701. [CrossRef]

157. Cai, R.T.; Nesi, G.; Boddi, V.; Mazzoli, S.; Dal Canto, M.; Bartoletti, R. Prognostic role of the tumor-associated tissue inflammatory reaction in transitional bladder cell carcinoma. Oncol. Rep. 2006, 16, 329-334. [CrossRef] [PubMed]

158. Di Salvo, E.; Casciaro, M.; Quartuccio, S.; Genovese, L.; Gangemi, S. Do Alarmins have a potential role in autism spectrum disorders pathogenesis and progression? Biomulecules 2019, 9, 2. [CrossRef]

159. Melo-Gonzalez, F.; Hepworth, M.R. Functional and phenotypic heterogeneity of group 3 innate lymphoid cells. Immunology 2017, 150, 265-275. [CrossRef]

160. Whiters, D.R.; Hepworth, M.R. Group 3 Innate Lymphoid Cells: Communications Hubs of the Intestinal Immune System. Front. Immunol. 2017, 8, 1298. [CrossRef] [PubMed]

161. Lim, A.I.; Di Santo, J.P. ILC-poiesis: Ensuring tissue ILC differentiation at the right place and time. Eur. J. Immunol. 2018. [CrossRef] [PubMed]

162. Vivier, E.; Artis, D.; Colonna, M.; Diefenbach, A.; Di Santo, J.P.; Eberl, G.; Koyasu, S.; Locksley, R.M.; McKenzie, A.N.J.; Mebius, R.E.; et al. Innate Lymphoid Cells: 10 Years On. Cell 2018, 174, 1054-1066. [CrossRef] [PubMed]

163. Montaldo, E.; Vacca, P.; Vitale, C.; Moretta, F.; Locatelli, F.; Mingari, M.C.; Moretta, L. Human innate lymphoid cells. Immunol. Lett. 2016, 179, 2-8. [CrossRef] [PubMed]

164. Kabata, H.; Moro, K.; Koyasu, S. The group 2 innate lymphoid cell (ILC2) regulatory network and its underlying mechanisms. Immunol. Rev. 2018, 286, 37-52. [CrossRef] [PubMed]

165. Kawano, Y.; Roccaro, A.M.; Ghobrial, I.M.; Azzi, J. Multiple Myeloma and the Immune Microenvironment. Curr. Cancer Drug Targets 2017, 17, 806-818. [CrossRef] [PubMed]

166. Spisek, R.; Kukreja, A.; Chen, L.C.; Matthews, P.; Mazumder, A.; Vesole, D.; Jagannath, S.; Zebroski, H.A.; Simpson, A.J.; Ritter, G.; et al. Frequent and specific immunity to the embryonal stem cell-associated antigen SOX2 in patients with monoclonal gammopathy. J. Exp. Med. 2007, 204, 831-840. [CrossRef] [PubMed]

167. Lesokhin, A.M.; Ansell, S.M.; Armand, P.; Scott, E.C.; Halwani, A.; Gutierrez, M.; Millenson, M.M.; Cohen, A.D.; Schuster, S.J.; Lebovic, D. Nivolumab in Patients With Relapsed or Refractory Hematologic Malignancy: Preliminary Results of a Phase Ib Study. J. Clin. Oncol. 2016, 34, 2698-2704. [CrossRef] [PubMed]

168. Pianko, M.J.; Funt, S.A.; Page, D.B.; Cattry, D.; Scott, E.C.; Ansell, S.M.; Borrello, I.M.; Gutierrez, M.; Lendvai, N.; Hassoun, H.; et al. Efficacy and toxicity of therapy immediately after treatment with nivolumab in relapsed multiple myeloma. Leuk. Lymphoma. 2017, 59, 1-4. [CrossRef] [PubMed]

169. Cavalli, G.; Dinarello, C.A. Anakinra Therapy for Non-cancer Inflammatory Diseases. Front. Pharmacol. 2018, 9, 1157. [CrossRef] [PubMed]

170. Simon, A.; Asli, B.; Braun-Falco, M.; De Koning, H.; Fermand, J.-P.; Grattan, C.; Krause, K.; Lachmann, H.; Lenormand, C.; Martinez-Taboada, V.; et al. Schnitzler's syndrome: Diagnosis, treatment, and follow-up. Allergy 2013, 68, 562-568. [CrossRef] [PubMed]

(C) 2019 by the authors. Licensee MDPI, Basel, Switzerland. This article is an open access article distributed under the terms and conditions of the Creative Commons Attribution (CC BY) license (http://creativecommons.org/licenses/by/4.0/). 